\title{
The Orogenic Crixás Gold Deposit, Goiás, Brazil: A Review and New Constraints on the Structural Control of Ore Bodies
}

\author{
Stanislav Ulrich ${ }^{1, *} \mathbb{1}$, Steffen Hageman ${ }^{2}$, Juliana Charão Marques ${ }^{3}(0)$, Frederico Lana A. R. Figueiredo ${ }^{4}$, \\ João E. F. Ramires ${ }^{4}$, José Carlos Frantz ${ }^{3}$ (1) and Klaus Petersen ${ }^{5}$ \\ 1 AngloGold Ashanti Australia, 140 St. Georges Terrace, Perth, WA 6000, Australia \\ 2 Centre for Exploration Targeting, The University of Western Australia, 35 Stirling Highway, \\ Crawley, WA 6009, Australia; steffen.hagemann@uwa.edu.au \\ 3 Laboratório de Geologia Isotópica, Departamento de Geologia, Universidade Federal do Rio Grande do Sul, \\ Av. Bento Gonçalves 9500, Porto Alegre 91501-970, Brazil; juliana.marques@ufrgs.br (J.C.M.); \\ jose.frantz@ufrgs.br (J.C.F.) \\ 4 Geology and Exploration Department, Mineração Serra Grande, AngloGold Ashanti, Crixás 76510-000, Brazil; \\ flarfigueiredo@hotmail.com (F.L.A.R.F.); JERamires@AngloGoldAshanti.com.br (J.E.F.R.) \\ 5 Target Latin America, Marista, Goiânia 74150-030, Brazil; klaus@targetlatinamerica.com \\ * Correspondence: sulrich@anglogoldashanti.com; Tel.: +61-478861452
}

check for updates

Citation: Ulrich, S.; Hageman, S.; Marques, J.C.; Figueiredo, F.L.A.R.; Ramires, J.E.F.; Frantz, J.C.; Petersen, K. The Orogenic Crixás Gold Deposit, Goiás, Brazil: A Review and New Constraints on the Structural Control of Ore Bodies. Minerals 2021, 11, 1050. https://doi.org/10.3390/min 11101050

Academic Editor: Stefano Salvi

Received: 13 August 2021

Accepted: 21 September 2021

Published: 28 September 2021

Publisher's Note: MDPI stays neutral with regard to jurisdictional claims in published maps and institutional affiliations.

Copyright: (c) 2021 by the authors. Licensee MDPI, Basel, Switzerland. This article is an open access article distributed under the terms and conditions of the Creative Commons Attribution (CC BY) license (https:// creativecommons.org/licenses/by/ $4.0 /)$.

\begin{abstract}
A review of the current knowledge of lithostratigraphy, geochronology, mineralogy, alteration, fluid chemistry and structural data is provided in order to discuss the main controls on mineralization in the Crixás gold deposit and the existing structural framework and evolution. Gold mineralization at Crixás represents orogenic upper mesothermal to lower hypothermal types developed within the overturned Paleoproterozoic (Rhyacian) stratigraphic sequence. The structural data indicates that upright folding of the stratigraphy and formation of a distinct S1 foliation characterizes D1 deformation. This controls the formation of laminated quartz veins, precipitation of Au-rich sulfides, and the development of NW trending orebodies. Localized F2 folding of D1 structures and strong L2 stretching lineations characterizes the D2 event. This localized F2 folding created oreshoots trending W-WNW within distinct orebodies. The D2 deformation is associated with the precipitation of native Au. The 'bulk plunge' of these orebodies is a combination of both plunges defined by D1 and D2 deformation events. A critical assessment of lithostratigraphic and structural data reveal two possible tectonic scenarios operating during the Paleoproterozoic. The first possible tectonic scenario considers sagduction and the development of a regional-scale synclinorium, followed by tilting and localized folding of D1 structures. The second scenario, which is similar to the current model, considers accretion producing a synclinorium, followed by thrusting. Based on the current knowledge, both models are considered to be permissible and a series of focused research studies are proposed to test both the current and the new tectonic models.
\end{abstract}

Keywords: gold mineralization; Crixás Greenstone Belt; tectonics

\section{Introduction}

The orogenic mesothermal Crixás gold deposit is located in the highly metal-endowed Archean-Paleoproterozoic Crixás-Goiás Terrane in Central Brazil. The terrane consists of five greenstone belts embedded within Archean trondhjemite-tonalite-granodiorite (TTG) complexes (Figure 1). The Crixás Greenstone Belt contains Archean ultramafic and mafic metavolcanic rocks and a Paleoproterozoic metasedimentary sequence. The stratigraphy, hydrothermal alteration, geochronology and tectonics of the belt have been presented in numerous publications (e.g., [1-4]). Recently, [3] provided a detailed update on the stratigraphy, geology and tectonic evolution of the Crixás Greenstone Belt. The latter was interpreted as a series of separate tectonic events, starting with Archean ocean floor spreading and sagduction, Paleoproterozoic basin opening, inversion, primary Paleoproterozoic thrusting and mineralization, secondary Neoproterozoic thrusting of the Mara 
Rosa volcanic arc and final orogenic docking during the Brasiliano Orogeny (Table 1). The gold mineralization is traditionally linked to the E-verging, thrusts and folds associated with the overturning of the stratigraphy (e.g., $[5,6])$. This tectonic model also established so-called 'Structures', namely Structures III, IV and the Palmeiras Structure (Figure 2). They represent major thrust planes linking deformation and channelized hydrothermal fluid flow. The age of the mineralization is usually linked to the Rhyacian (e.g., [3,4]), although early works suggested a Brasiliano age (e.g., $[1,7])$.

A strong prolate shape of orebodies represents the key characteristics of the Crixás gold deposit. However, deposit-scale structural data have not been published in a peerreviewed article yet, despite numerous high-quality structural studies that were carried out by the Crixás exploration team, external consultants and University students. This work aims to fill this gap and present outcrop scale structural observations and data from five orebodies in the Crixás deposit, namely Mina III, Ingá, Corpo IV, Pequizão and Palmeiras. The new structural data and interpretation is augmented by succinct reviews of the current knowledge of stratigraphy, metamorphism, hydrothermal alteration, mineralization and hydrothermal fluids, and geochronology.

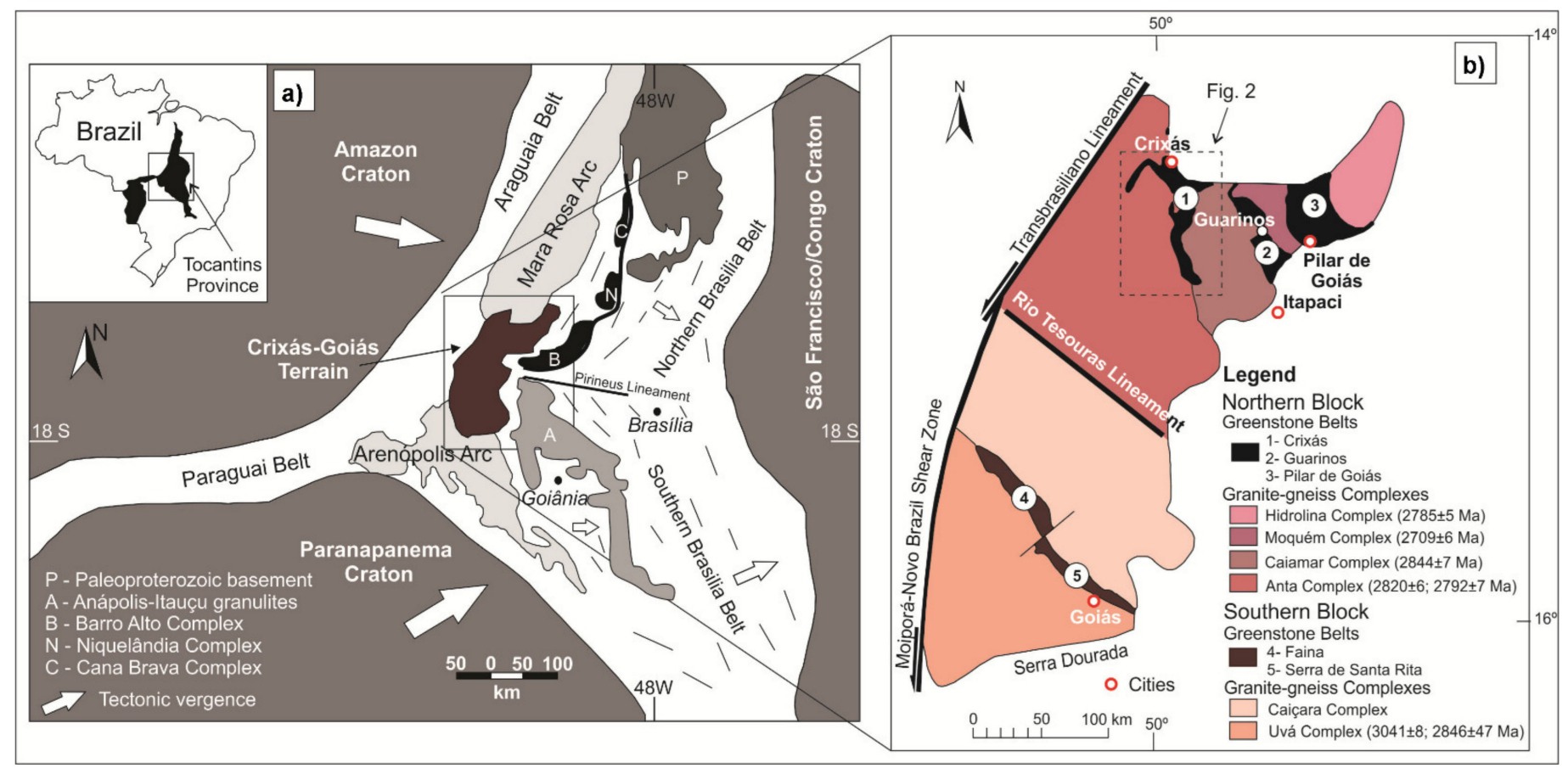

Figure 1. (a) Location of the Archean-Paleoproterozoic Crixás-Goiás Terrane in the Tocantins Province. From [4] after [8,9]. (b) Subdivisions of the main components of the Crixás-Goiás Terrane. Modified from [4] after [2]. Ages are from [10,11]. 
Table 1. Summary of presented structural schemes. Absolute times not provided because of a paucity of geochronological data related to deformation. D0A-deposition of the Archean extrusives; D0P-deposition of the Paleoproterozoic basin. Ages of D0A and D0P are provided in the Chapter 7. Green background-gold in sulfides mineralization; Yellow background-free milling gold mineralization.

\begin{tabular}{|c|c|c|c|c|c|}
\hline & $\begin{array}{c}{[12]} \\
\text { Kuyumjian \& } \\
\text { Araujo Filho, } 1984\end{array}$ & $\begin{array}{c}\text { [13] } \\
\text { Thompson, } \\
1991 \\
\end{array}$ & $\begin{array}{c}{[2,3]} \\
\text { Jost et al., } \\
2010 \& 2019\end{array}$ & $\begin{array}{l}\text { [4] } \\
\text { Ferreira et al., } \\
2021\end{array}$ & This Work \\
\hline \multirow[b]{2}{*}{ 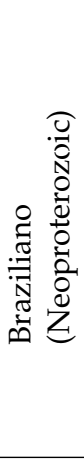 } & $\begin{array}{l}\text { D5 } \\
\text { Upright folding, } \\
\text { F5ax: N-S to N30W }\end{array}$ & $\begin{array}{c}\text { D4 } \\
\text { Crenulation of the } \\
\text { thrust-related } \\
\text { foliation }\end{array}$ & $\begin{array}{l}\text { D4 } \\
\text { E-W compression, } \\
\text { Crenulation }\end{array}$ & & $\begin{array}{l}\text { D4 } \\
\text { E-W compression, } \\
\text { Crenulation }\end{array}$ \\
\hline & & $\begin{array}{l}\text { D3 } \\
\text { Top-to-the-E } \\
\text { thrusting, } \\
\text { Mineralization }\end{array}$ & $\begin{array}{c}\text { D3 } \\
\text { S-thrusting of Mara } \\
\text { Rosa magmatic arc, } \\
\text { Rio Vermelho } \\
\text { Antiform, Recumbent } \\
\text { F3 plunging WNW, } \\
\text { Gold remobilization }\end{array}$ & $\begin{array}{c}\text { Stage } 3 \\
\text { S-thrusting of } \\
\text { Mara Rosa } \\
\text { magmatic arc, } \\
\text { Partial resetting of } \\
\text { detrital zircons in } \\
\text { Córrego Geral } \\
\text { Formation }\end{array}$ & $\begin{array}{c}\text { D3 } \\
\text { S-thrusting of Mara } \\
\text { Rosa magmatic arc, S3 } \\
\text { schistosity in the } \\
\text { hangingwall of the Rio } \\
\text { de Bois thrust }\end{array}$ \\
\hline \multirow{4}{*}{ 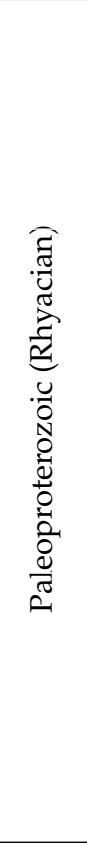 } & & & & & $\begin{array}{c}\mathrm{D} 2 \\
\text { Tilting of S1 and V1, } \\
\text { Recumbent folding F2, } \\
\text { L2 stretching, } \\
\text { Free-milling gold } \\
\text { mineralization }\end{array}$ \\
\hline & & & $\begin{array}{l}\mathrm{D} 2 \\
\text { Semi-recumbent folds } \\
\text { F2, Thin-skinned } \\
\text { thrusting, Overturn of } \\
\text { the stratigraphy, } \\
\text { Gold mineralization }\end{array}$ & $\begin{array}{c}\text { Stage } 2 \\
\text { Folding, } \\
\text { NE-verging thrust, } \\
\text { Gold } \\
\text { mineralization, } \\
\text { Local high-strain } \\
\text { mylonitization }\end{array}$ & $\begin{array}{c}\text { D1 } \\
\text { Sagduction and } \\
\text { regional synclinorium, } \\
\text { Isoclinal upright } \\
\text { folding F1, V1 quartz } \\
\text { veins, Massive and } \\
\text { disseminated sulfides } \\
\text { and gold } \\
\text { mineralization }\end{array}$ \\
\hline & & & $\begin{array}{l}\text { D1 } \\
\text { Tight to isoclinal folds } \\
\text { F1, S1 parallel to S0, } \\
\text { metamorphic fabric }\end{array}$ & & \\
\hline & & & \multicolumn{3}{|c|}{$\begin{array}{l}\text { D0P, Stage } 1-\text { Rifting } \\
\text { basin and clastic input from Rhyacian arc, } \\
\text { Nonconformity }\end{array}$} \\
\hline \multirow{5}{*}{ 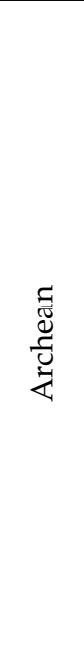 } & $\begin{array}{l}\text { D4 } \\
\text { Upright folding, } \\
\text { Rio Vermelho } \\
\text { anticline }\end{array}$ & \multirow{4}{*}{$\begin{array}{c}\text { D1-2 } \\
\text { Isoclinal folding, } \\
\text { Archean nappes, } \\
\text { Inverted } \\
\text { stratigraphy }\end{array}$} & \multirow{4}{*}{ Sagduction } & & \\
\hline & $\begin{array}{l}\text { D3 } \\
\text { Recumbent folds, } \\
\text { 2nd refolding } W \\
\text { plunging }\end{array}$ & & & & \\
\hline & $\begin{array}{c}\mathrm{D} 2 \\
\text { Sagduction, } \\
\text { 1st refolding }\end{array}$ & & & & \\
\hline & $\begin{array}{c}\text { D1 } \\
\text { Semi-recumbent } \\
\text { folds, } \\
\text { synclinorium }\end{array}$ & & & & \\
\hline & & & $\begin{array}{c}\text { D0A } \\
\text { nafic ar }\end{array}$ & & \\
\hline
\end{tabular}




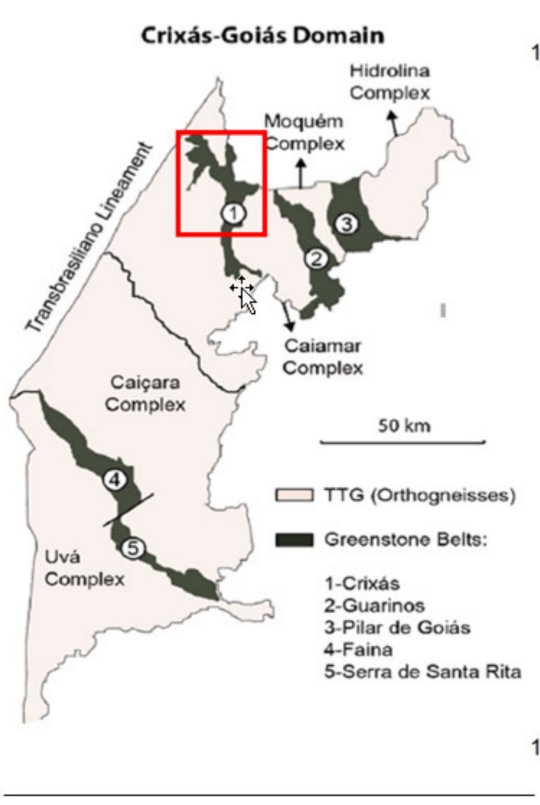

Crixás Greenstone Belt

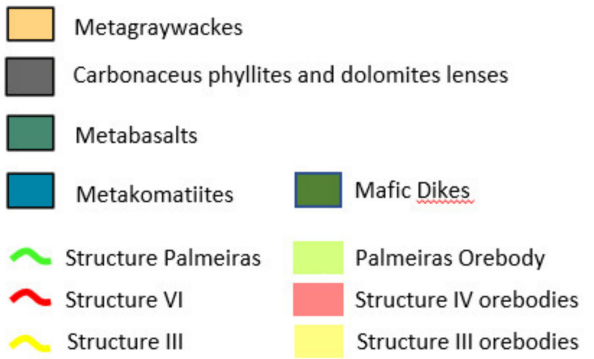

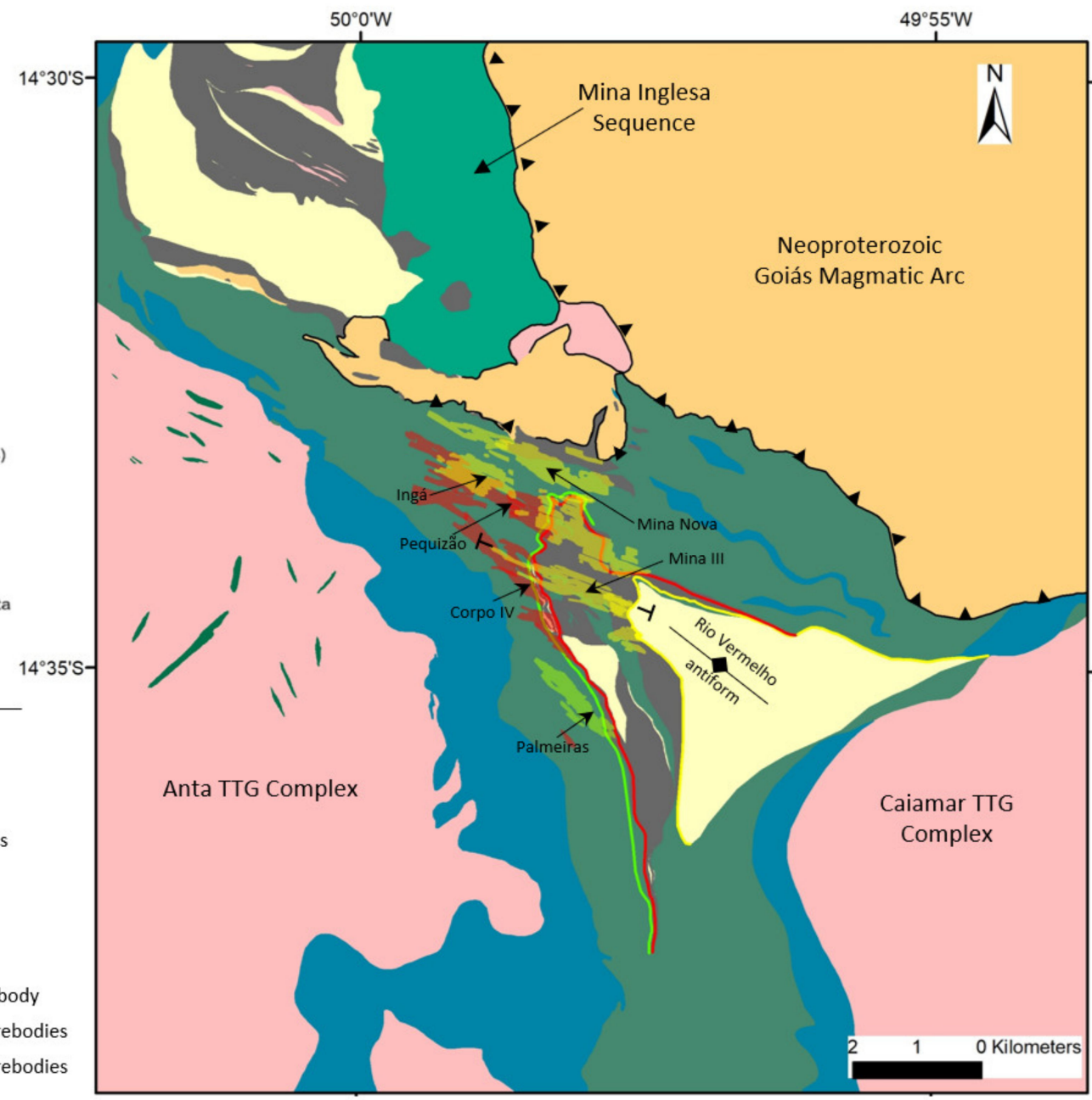

Figure 2. Geological map of the Central to Northern Domain of the Crixàs Greenstone Belt based on a long term exploration work of AGA team. Main orebodies and traces of ore horizons named as 'Structures' are projected on the map.

\section{Regional Geological Setting: Crixás Greenstone Belt}

The Archean-Paleoproterozoic Crixás-Goiás Terrane is located in the central portion of the Tocantins Province and was assembled during the Neoproterozoic Brasiliano Orogeny (Figure 1; [8]). The Orogeny involves a collision of Paranapanema, Amazon and São Francisco/Congo cratons and a development of orogenic belts, known as Brasília, Paraguai, and Araguaia, between them. The orogenic belts also involve the Neoproterozoic Mara Rosa and Arenopolis magmatic arcs. The Brasília Belt consists of NE and SE branches that are crosscut by E-W shear zones, known as Pirineus Syntaxis [14]. The terrane is in the footwall of the thrust contact (Rio dos Bois Thrust-Fault) with the Neoproterozoic Mara Rosa magmatic arc to the north (Figure 2; [15]). The eastern boundary of the terrane comprises metasedimentary rocks of the Mesoproterozoic Serra da Mesa Group.

The Crixás-Goiás Terrane consists of Mesoarchean to Early Neoarchean TTG complexes and five greenstone belts in the form of the synformal keels $[10,11]$. The southern greenstone belts, called Faina and Serra de Santa Rita, both trend $\mathrm{N} 60^{\circ} \mathrm{W}$ and vary in metasedimentary rock sequences [16]. The other three belts trend N-S and, from the west to east, are called the Crixás, Guarinos, and Pilar de Goiás greenstone belts. All three northern belts have similar stratigraphy comprising Archean and Paleoproterozoic rocks, described in detail below. They are heterogeneously deformed and metamorphosed up to epidote-amphibolite facies conditions [17].

The Crixás Greenstone Belt is ca. $48 \mathrm{~km}$ long and on average $5 \mathrm{~km}$ wide. It forms a regional-scale synclinorium that is inclined and dips to the west in the Crixás gold deposit 
area. The Meso-to Neoarchean tonalitic to granodioritic Anta and Caiamar TTG Complexes bound the Crixás Greenstone Belt to the west and east, respectively [10]. Metavolcanosedimentary rocks of the Neoproterozoic Mara Rosa volcanic arc overthrust the belt to the north [18]. Mafic dikes and local diorite stocks occur within the orthogneiss complexes adjacent to the Crixás Greenstone Belt $[3,19]$. The dikes are preferably oriented NW-SE, varying from a few meters up to hundreds of meters in width and from 1.0 to $15 \mathrm{~km}$ in length. Mafic dikes also crosscut the Crixás Greenstone Belt lithostratigraphy based on numerous drill hole intersections.

\section{Crixás Gold Camp-History of Exploration, Mining and Scientific Research}

The history of the Crixás gold deposit begins in the 18th century when the Bandeirantes explored the area and discovered gold from alluvial deposits. Artisanal workings quickly started inside the main outcropping gold occurrences. Significant exploration and smallscale mining activities began in the mid-1970s following a regional exploration program of the joint venture partners Inco and Kennecott, which resulted in the discovery of the large Mina III orebody. Serra Grande S. A., a joint venture between the companies Morro Velho and Inco, started underground production in 1989. In 2012, AngloGold Ashanti became the single owner of the Crixás deposit and continues to operate to the present day as Mineração Serra Grande. The Mina III orebody has been in production since its discovery and has produced more than $3 \mathrm{Moz}$ of gold. The exploration activities led to several other underground and surface discoveries that are known as Pequizão, Mina Nova, Palmeiras, Corpo IV and Ingá orebodies. Drilling performed between 1976 and 2020 obtained 1,968,735 $\mathrm{m}$ of drill-cores from within the mineral rights area of the company. Production during the past 30 years resulted in $4.45 \mathrm{MOz}$ gold with an annual production of approximately $110-186 \mathrm{kOz}$ and gold grades ranging between $3-8 \mathrm{~g} / \mathrm{t}$. Additional underground and regional exploration targets are explored and continuously added to the resource and reserves annually (https:/ / www.anglogoldashanti.com/portfolio/americas/ serra-grande/, accessed on 10 August 2021).

Discovered ore bodies so far are located on so-called 'Structures' that are named from top to bottom as follows: (a) Palmeiras structure that hosts Palmeiras orebody; (b) Structure IV that hosts Pequizao, Corpo IV, Forquilha, Corpo V and Palmeiras Sul orebodies; (c) Structure 3.5 that hosts Palmeiras South 3.5 orebody, Structure III Upper zone that hosts Zona Superior orebody, and Structure III Lower zone (or Zona Inferior) that hosts Mina III, VQZ deep, Minas Nova and Inga orebodies (Figure 3).

The Crixás gold deposit and the surrounding area has been studied in detail by various government surveys, and Brazilian universities, particularly the University of Brasilia and the University of Rio Grande do Sul that still collaborate with the exploration team. Multiple aspects of gold mineralization have been addressed and are reviewed in the following text. 


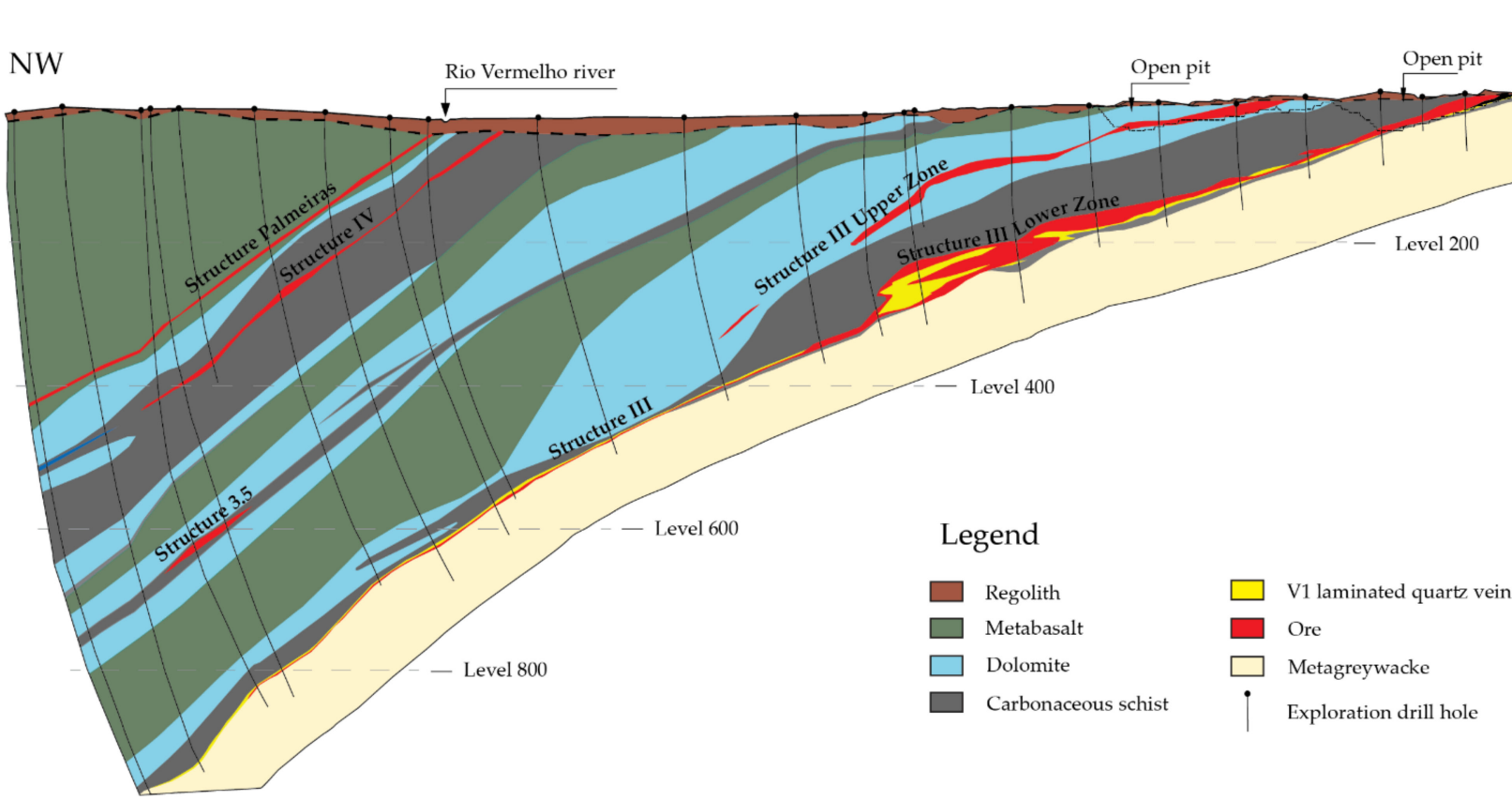

Figure 3. Geological long section is based on logging of exploration drill holes from Crixàs Gold Deposit and show relative positions of individual mineralized Structures. See geological map in Figure 2 for a line of the long section.

\section{Lithostratigraphic Setting and Metamorphism of the Crixás Greenstone Belt}

The lithological composition of the Crixás Greenstone Belt belongs formally to the Crixás Group [2,20,21] (Figure 4). The Lower Subgroup includes Archean metakomatiites of the Córrego Alagadinho Formation and metabasalts (amphibolites) of the Rio Vermelho Formation. The Upper Subgroup consists of Paleoproterozoic metasedimentary sequences including carbonaceous phyllite and mica schists interbedded with dolomite-rich marbles of the Ribeirão das Antas Formation and a thick, siliciclastic sequence (metagraywackes) of the Córrego Geral Formation [3]. In the deposit area, the stratigraphic sequence is overturned, and orebodies are located predominantly within, as well as at the contacts of the Ribeirão das Antas Formation.

The Córrego Alagadinho Formation comprises komatiitic flows showing locally preserved spinifex texture, olivine cumulates, pillow basalts, flow breccias and polyhedral disjunctions [2,21,22]. It is up to $900 \mathrm{~m}$ thick in the southern and less than $500 \mathrm{~m}$ thick in the central and northern part of the greenstone belt [3]. The primary (igneous) mineralogy is olivine, orthopyroxene and chromite, partially transformed to metamorphic actinolite and magnetite. Locally, well-preserved komatiites and pillow basalts show serpentine-talcchlorite-tremolite-carbonate and chlorite-tremolite-quartz-pyrite assemblages, respectively. Those assemblages are interpreted by [23] as the result of hydrothermal seafloor alteration. In high strain zones, generally near the contact with the orthogneiss complexes, the rocks are transformed to talc schists with minor chlorite and magnetite [3]. 


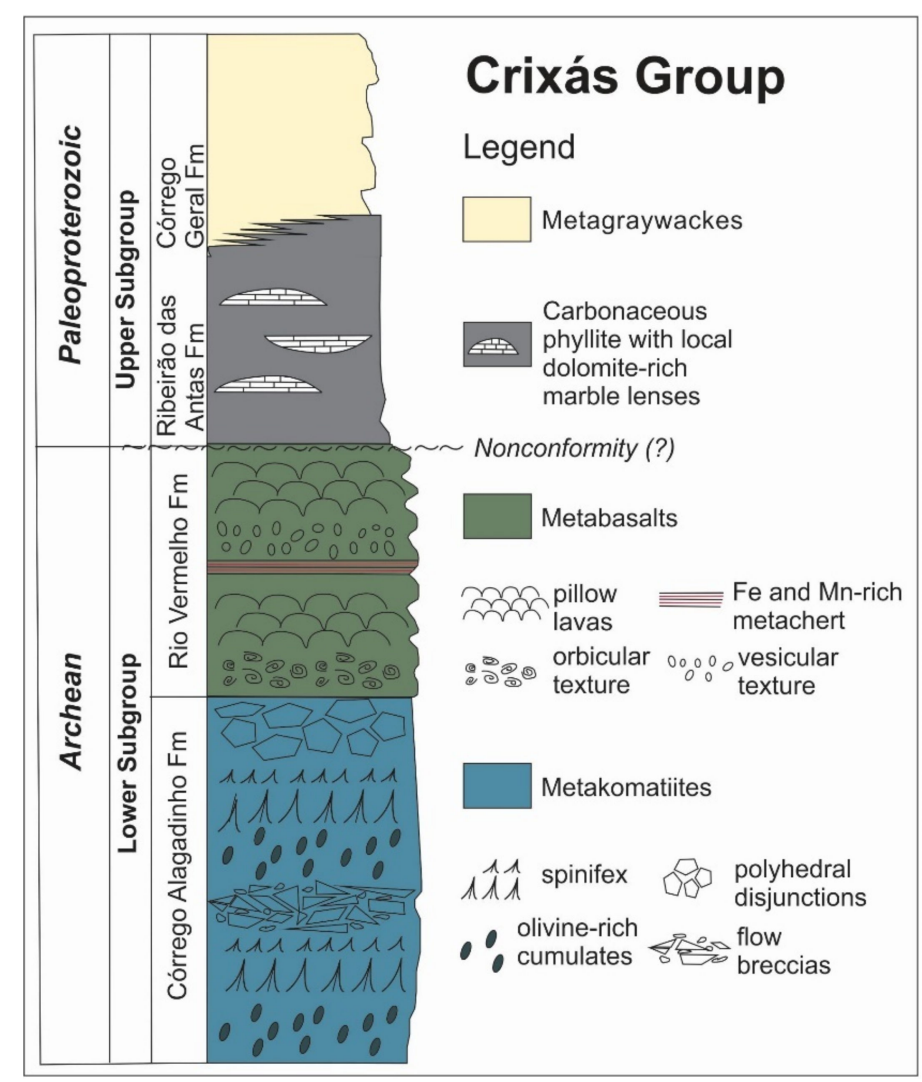

Figure 4. Stratigraphic section of the Crixás Greenstone Belt modified from [3].

The Rio Vermelho Formation consists of tholeiitic metabasalts with preserved primary volcanic features such as pillow lavas and variolitic, vesicular and orbicular textures $[2,3,23,24]$. The metabasalts have local intercalations of sub metric meta-chert bands, locally enriched in iron and manganese $[23,24]$. The Rio Vermelho Formation is circa $300 \mathrm{~m}$ thick and is composed of Fe-tremolite, oligoclase, and minor chlorite, clinozoisite, quartz, pyrite or magnetite, interpreted as indicative for seafloor alteration [3]. It is transformed into foliated amphibolites within high strain zones. Undeformed and foliated amphibolites were investigated in detail by $[1,7,17,25]$. According to these authors, the mineral assemblage of the undeformed amphibolite consists of hornblende-albite-zoisite-quartzilmenite, consistent with epidote-amphibolite facies. Both [26,27] note an assemblage of actinolite-zoisite-chlorite-albite-quartz-calcite-ilmenite, consistent with greenschist facies metamorphic grade of regional metamorphism. However, this assemblage can also represent a retrograde phase of the epidote-amphibolite facies metamorphism. Foliated amphibolite displays a metamorphic assemblage of hornblende-albite-zoisite-quartz, and is therefore the same as the undeformed amphibolite and consistent with the epidoteamphibolite metamorphic conditions and calculated temperature of $450-500{ }^{\circ} \mathrm{C}$ and pressures of $0.3-0.5 \mathrm{GPa}[1,7]$. A metasomatized zone represented by carbonate-chlorite schist characterizes the contact with the Ribeirão das Antas Formation.

The Ribeirão das Antas Formation crops out only in the central and northwestern deposit areas with an estimated thickness of around $400 \mathrm{~m}$. It is dominated by carbonaceous phyllites, schists and dolomite-rich marbles, and a variable amount of intercalated siliciclastic lenses. Metabasalts inliers are observed, particularly near the contact with the Rio Vermelho Formation [4] and have been studied by [7] in her thesis. The carbonaceous phyllites have a fine foliation and are generally intensely folded. Schists show lepidoblastic texture marked by flakes of micas, but frequently exhibit large crystals forming "mica fish". The siliciclastic rocks show bands composed of quartz with undulose extinction and minor albite and/or amphibole in a granoblastic texture and very thin bands of mica forming a foliation, parallel to the rhythmic sedimentary lamination. The rocks of the Ribeirão 
das Antas Formation are heterogeneously affected by deformation and metamorphic and hydrothermal processes, producing a range of distinct lithologies such as chlorite schist, carbonate chlorite schist and minor sericite schist. Garnet chlorite schist is also common within the carbonaceous phyllites. Narrow bands of high strain are observed, producing a mylonitic foliation marked by stretching and dynamic recrystallization, mainly of quartz. These high strain bands frequently show rotated porphyroclasts of K-feldspar and garnet, and stretched sedimentary sulfides [4]. There is a distinct lack of metamorphic studies for rocks of the Ribeirao das Antas Formation. Based on the low crystallinity of carbonaceous matter in carbonaceous phyllites, [3] proposed a low to medium greenschist facies metamorphic grade for these rocks. At the top of the Ribeirão das Antas Formation, at the transitional contact to the Córrego Geral Formation, the amount of siliciclastic rocks interbedded in the carbonaceous phyllites and dolomite increases. The siliciclastic rocks are fine-grained with irregular rhythmic lamination and are composed of quartz, K-feldspar, white mica, small angular lithic fragments, albite, minor biotite and garnet [3,4].

The Córrego Geral Formation is composed of monotonous, siliciclastic meta-graywackes and meta-turbidites [3,4]. The formation is only observed at the bottom of exploration holes and in outcrops of the central and northern sectors of the Crixás Greenstone Belt. They have an estimated thickness of at least $300 \mathrm{~m}$ [3]. The metamorphism has been considered to reach greenschist facies conditions due to the presence of metamorphic chlorite, biotite, and white mica [3]. However, the siliciclastic meta-graywackes are indistinguishable from those siliciclastic intervals interbedded in the Ribeirão das Antas Formation. They show similar composition, metamorphic paragenesis and microstructures, including rotated K-feldspar and garnet, and "mica fish" microstructures. The Córrego Geral Formation reached at least medium greenschist facies metamorphic grade, and the absence of stretched sulfides is the only difference to the siliciclastic rocks of the Ribeirão das Antas Formation [4].

\section{Structural Setting}

\subsection{Existing Structural Schemes and Models}

The first deformation history of the Crixás Greenstone Belt was provided by [12]. They argued for pre-greenstone extensional structures D0, followed by an Archean diapiric rise of TTG domes associated with folding and refolding during D1-D4, and finally a long-wavelength folding event D5 during the Neoproterozoic Brasiliano Orogeny (Table 1).

An ESE-verging thrust fault was identified in the Structure III Lower Zone, based on the apparent juxtaposition of the epidote-amphibolite rocks of the Ribeirão das Antas Formation over greenschist facies grade metasedimentary rocks of the Córrego Geral Formation [7]. The kinematics of the thrust fault was based on S-shaped inclusion trails in garnet porphyroblasts and a strong stretching lineation plunging to the WNW that defines a non-coaxial deformation and a transport direction of the thrusting to the ESE [13]. However, symmetric boudins stretched parallel to the stretching lineation were also described, indicating coaxial deformation and a layer parallel extension, and thus not thrusting, e.g., $[28,29]$. The S-shaped inclusion trails in garnets remain the only kinematic indicators provided [13], and doubts exist over their interpretation based on the model of [30]. She proposed three deformation phases, with the latest to be related to the thrusting, instead of one continuous thrusting event, which is more commonly applied today (e.g., [31]), where garnets rotate progressively in the simple shear.

The structural scheme used today, called the current structural scheme in the following text, was introduced in the 1990s (e.g., [5,32,33]). A model that involves Archean sagduction and two Paleoproterozoic and two Neoproterozoic deformation phases has been proposed (Table 1 and Figure 5; [2,3]). The D1 phase resulted in the isoclinal folding of bedding (S0 parallel to S1) and regional metamorphism, reaching epidote-amphibolite facies conditions. The D2 is associated with semi-recumbent folding, stratigraphic overturning, and thinskinned thrusting to the NE. 


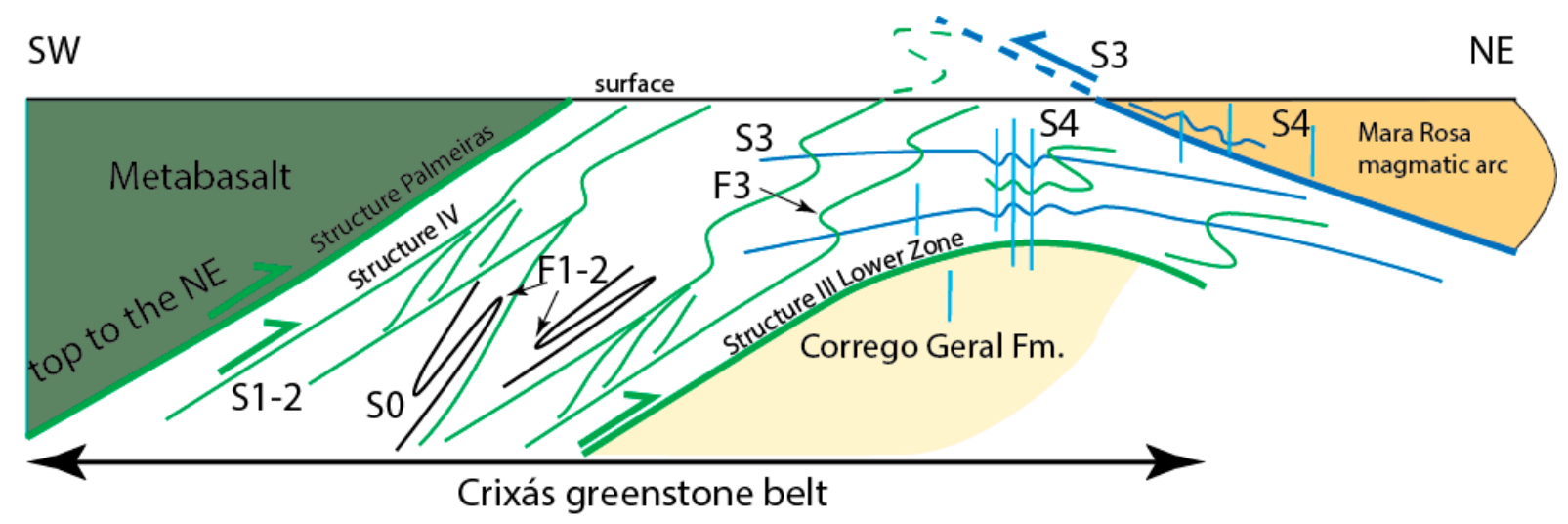

Figure 5. A summary sketch of the current structural framework.

The D3 deformation event has been linked to the Neoproterozoic top-to-the-S movement of the volcaniclastic rocks of the Mara Rosa magmatic arc on the Rio dos Bois thrust-fault (Figure 5; e.g., [3,15]). The D3 event is also linked to the formation of a strong stretching lineation parallel to the recumbent fold axes, both plunging to the WNW [2]. The formation of the Rio Vermelho antiform trending NW-SE (Figure 2) has been linked to this event as well [2]. The latest D4 event was characterized as E-W compression that formed N-S trending, vertical crenulation cleavage reworking all previously developed foliations in rocks of the Crixás Greenstone Belt as well as the Mara Rosa magmatic arc (Figure 5; [2,4]).

\subsection{New Structural Data}

The structural evolution of the Crixás gold deposits has been studied by the authors in numerous underground exposures within and outside individual orebodies and in the oriented diamond cores. Important complementary observations and data come from structural mapping in open pits and natural outcrops. Three deformation phases have been recognized and described within the deposit using the current deformation scheme. It is noteworthy that D1 folds refolded by D2 [2] have not been observed by the authors. Therefore, the D1 and D2 deformation features, established by [2], have not been recognized as a separate deformation event. They are both referred to as D1 in the model presented below.

The D1 deformation is associated with the dominant $\mathrm{S} 1$ foliation that defines the peak metamorphic assemblage. The $\mathrm{S} 1$ foliation is axial planar to the $\mathrm{F} 1$ folds and dips gently to the NW (Figure 6). The F1 folds are developed dominantly in laminated, siliciclastic rocks and the F1 fold hinges are usually preserved in between orebodies (Figure 6a). The S1 foliation is commonly parallel to the $\mathrm{S} 0$ within the fold limbs and usually dips to the W-SW at a moderate angle (e.g., in the Corpo IV, Pequizão and Palmeiras orebodies. Towards the N-NE, however, it flattens, and northwest of the Crixás deposits it dips gently to the NE (Figure 6d,e), e.g., in the Ingá and Mina III orebodies). This spatial change of the S1 geometry defines the NW-SE trending Rio Vermelho antiform [5] at the regional scale (Figure 2). Continuous and up to $\sim 1 \mathrm{~m}$ thick laminated, crack-seal type quartz veins (V1) occur parallel to the S1 foliation within the carbonaceous schists in the Structure III Lower Zone and the Structure IV (Figure 6c). The S1 planes usually contain a stretching lineation gently plunging towards NW to W, but it is unclear if this represents the L1 or the more common L2 lineation associated with D2 structures. 

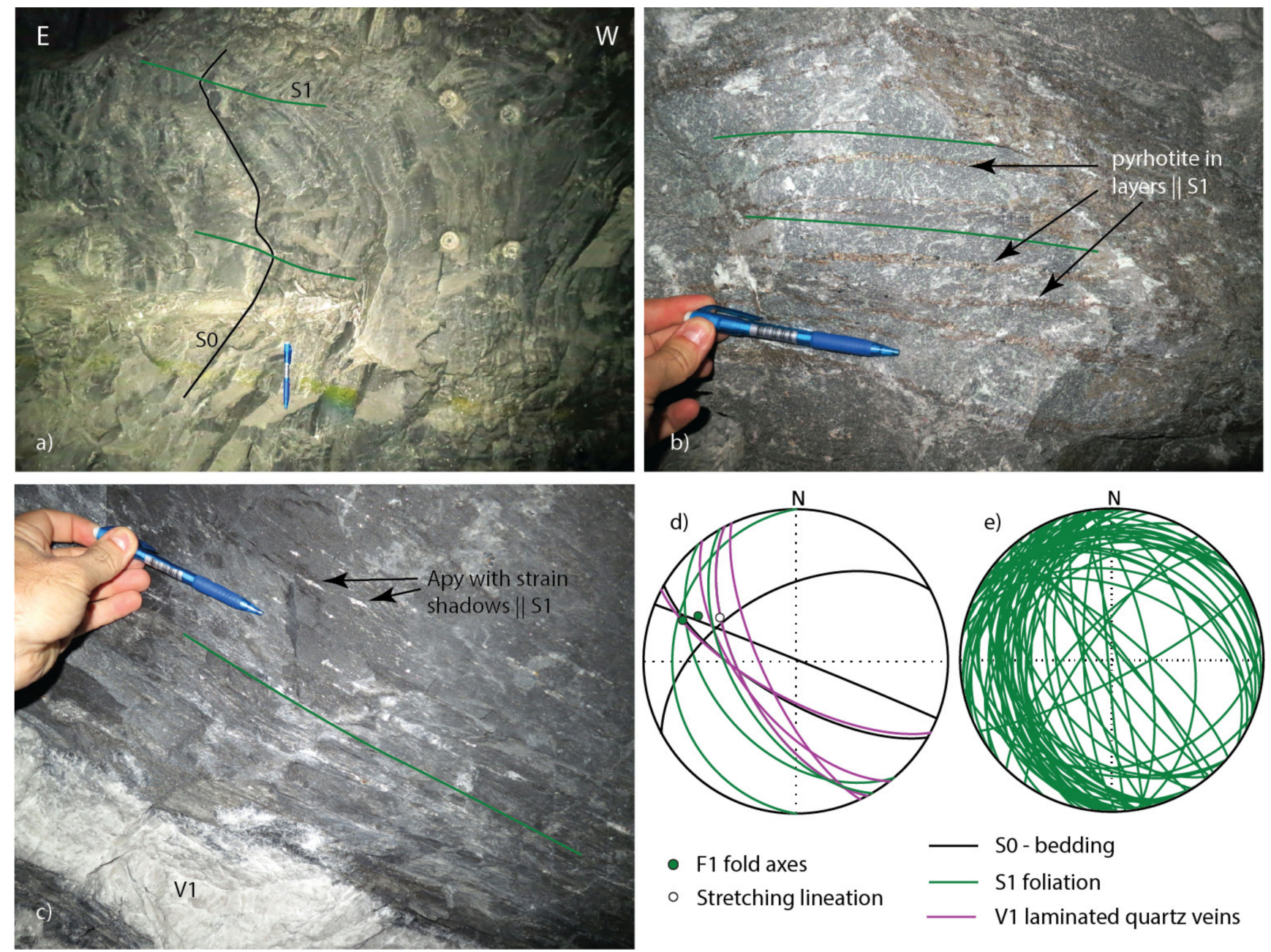

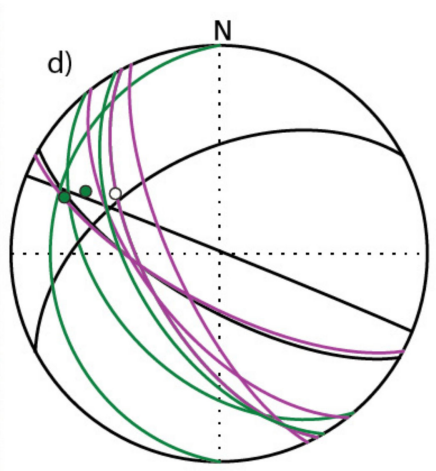

- F1 fold axes

- Stretching lineation

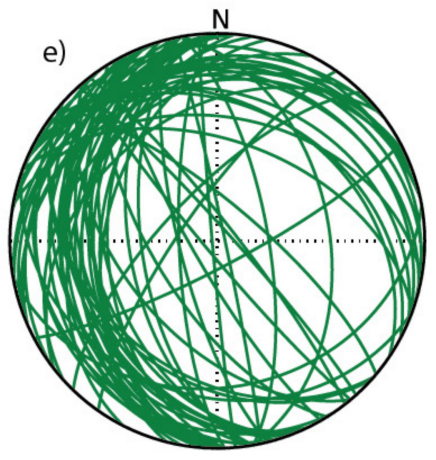

So - bedding

S1 foliation

V1 laminated quartz veins

Figure 6. Structures related to the D1 deformation event. (a) Incipient folding of bedding within siliciclastic rocks between Structure III and Structure IV; (b) Pyrrhotite-dominated sulfide layers are parallel to the S1 foliation in the Palmeiras Structure; (c) Strong S1 foliation contains disseminated, euhedral arsenopyrites with strain shadows that are parallel to the S1 as well as laminated V1 vein; (d) Planar (great circles) and linear (points) structural data from outcrops presented in (a-c); (e) All S1 foliations from underground exposures (great circles).

The D2 deformation is localized and commonly affects laminated quartz veins and surrounding S1 foliation. It is defined by recumbent, tight and asymmetric S-folds (Figure 7a,d). A secondary foliation S2 is axial planar to F2 folds, having a gentle dip angle and variable strike (Figure $7 b, c)$. The $S 2$ foliation in the laminated quartz veins is semi-brittle and appears as fracture cleavage locally refracting from the geometry of the S2 foliation in the wall-rocks. A distinct geometry and crosscutting relationship between S1 and S2 foliations are observed within F2 hinges, which plunge gently to the WNW. The F2 hinges are usually oriented parallel to strongly developed stretching lineation L2, gently plunging to the WNW (Figure 7b). Quartz, carbonate and sulfide-bearing V2 tension gashes opened perpendicular to the L2s. The tension gashes strike NNE and fill the necks of boudinaged laminated V1 veins or carbonaceous schists (Figure 7f). Locally, the tension gashes are folded with axial planes oriented parallel to the S1 foliation (Figure 7g). The Mina III open-pit encompassing the Mina III orebody on the Structure III Lower Zone shows additional structural elements associated with the D2 deformation event (Figure 7a,b); e.g., margins of laminated veins show striations plunging to the $\mathrm{S}$ and $\mathrm{N}$, oriented perpendicular to fold axes (Figure 7b). Finally, there are also bulky and irregular V3 tension gashes consisting of quartz, carbonate and locally pyrrhotite. They are usually observed in a proximity to F2 folds in laminated quartz veins (Figure 7d). 


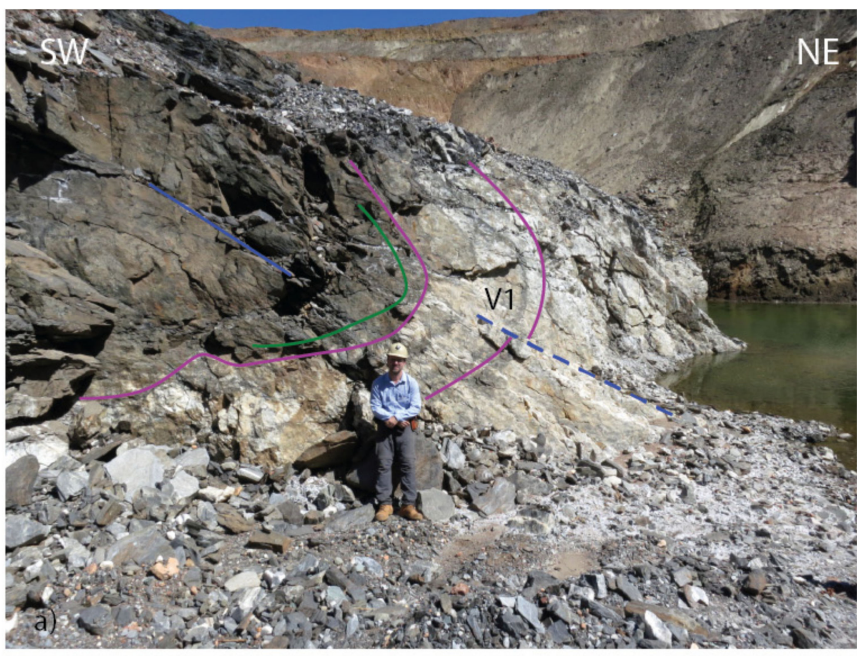

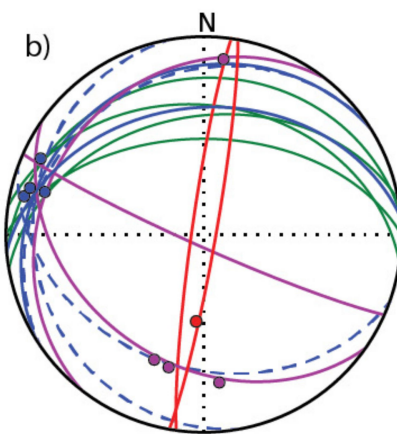

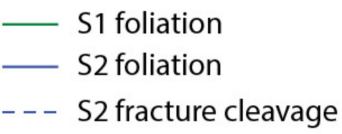

- L2 stretching lineation

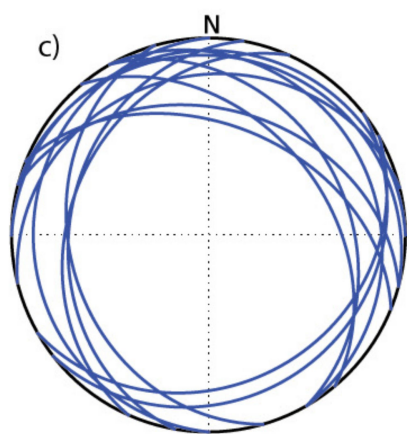

V1 laminated quartz vein

- Striation on the V1 margin

- Tension gash wall

- V2 tension gash neck axis
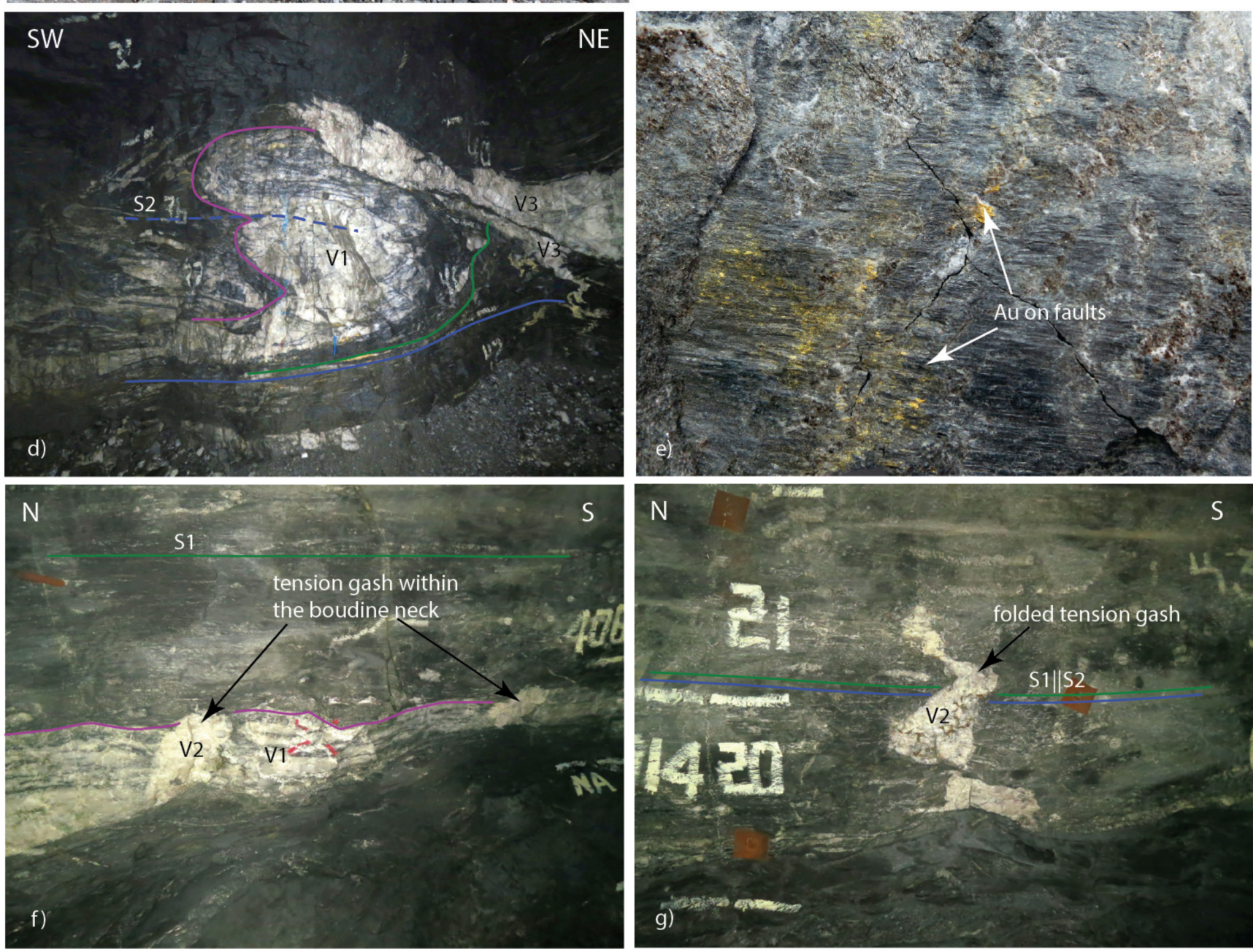

Figure 7. Structures related to the D2 deformation event. (a) Hinge of meters thick laminated quartz vein in the Mina III open pit; (b) Planar (great circles) and linear (points) structural data collected in the outcrop in A within the Mina III open pit; (c) S2 foliations (great circles) measured underground in the close vicinity to the folded laminated veins; (d) Typical structural scenario within the ore zone of the Structure III. Recumbent folding of laminated quartz veins within sulfide-bearing carbonaceous schists; (e) Native gold on fault surfaces of reactivated laminated quartz vein margins; (f) Quartz-carbonate tension gashes fill necks of boudinaged laminated quartz vein in the Pequizao orebody; (g) Folded quartz-carbonate-pyrrhotite tension gash within carbonaceous schist in the Pequizao orebody. 
The D3 deformation event is recorded as a penetrative S3 schistosity in the metavolcaniclastic sequence of the Mara Rosa magmatic arc gently dipping to the NNE [2] (Figure 8a). These rocks occur in the hangingwall of the Rio dos Bois thrust fault north of the Crixás deposit and were not a subject of detailed structural analysis in this work.
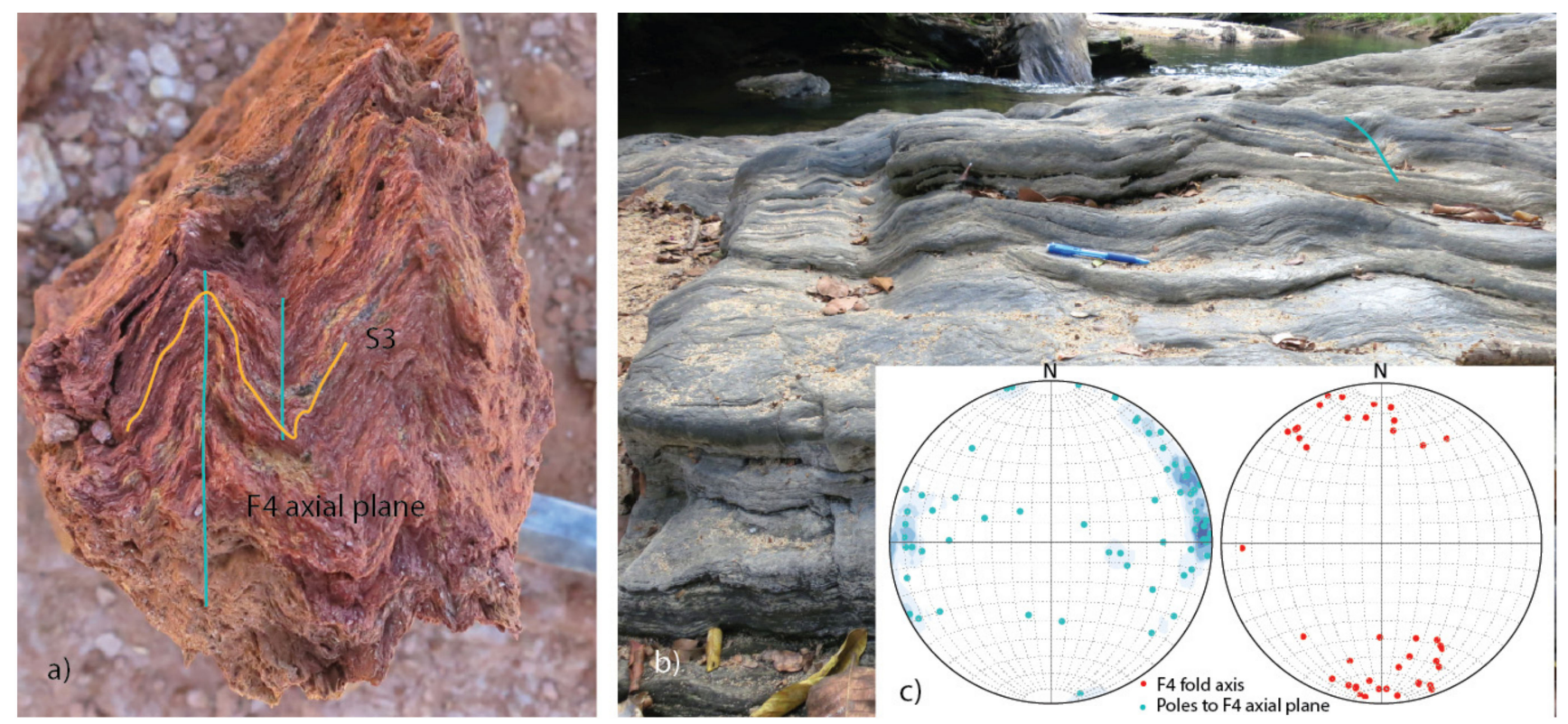

Figure 8. Structures related to the D3 and D4 deformation events. (a) Upright F4 kink folding of volcano-sedimentary rocks of the Neoproterozoic Mara Rosa Magmatic arc. (b) Upright F4 folding of bedding in a meta-turbiditic sequence of the Córrego Geral Fm. (c) Stereoplots show the distribution of poles to F4 kink fold axial plane and F4 fold axis.

The D4 deformation is characterized by upright, open to close kink F4 folds with approximately $\mathrm{N}$ or $\mathrm{S}$ gently plunging fold axes and steep N-S trending axial fold planes (Figure $8 b$ ). There is some deviation of the fold axis trend and strike of the fold axial plane (Figure 8c). These F4 folds affect S1 foliation in both Rhyacian formations, as well as thrust-related S3 schistosity in the volcano-sedimentary sequence of the Neoproterozoic Mara Rosa magmatic arc to the $\mathrm{N}$.

\subsection{Ore Body Geometry}

All orebodies in the Crixás deposits show a strong linear shape with a shallow plunge (Figures 2 and 9), and the trend (black arrow in Figure 9) ranges from NW (in the Palmeiras orebody) to W-WNW (in the Mina III orebody). Exploration and mining experiences gathered over the years show that high-grade portions of orebodies (oreshoots) are parallel to the strong stretching lineation L2. However, orebodies are not always parallel to oreshoots within them. Stereoplots of linear structural data measured in the five main orebodies (Mina III, Ingá, Pequizaõ, Corpo IV and Palmeiras) are presented in Figure 8 to better understand controls on both, orebody and oreshoot, trend directions. Stretching lineation L1 and L2 from the exploration database are presented together, due to a high possibility of misidentification between L1 and L2 on reactivated S1 planes. Fisher mean orientation of linear structural data has been calculated for each orebody in the structural module of the Leapfrog Geo (Seequent) 3D modelling software and compared to the overall trend and plunge of the corresponding orebody. In the Mina III and Palmeiras orebodies, Fisher means show parallelism with both orebodies. It is noteworthy that F2 folds have not been observed in the Palmeiras orebody, whereas these F2 folds are characteristic for the Mina III orebody. In the Ingá, Pequizaõ and Corpo IV orebodies, the Fisher means deviate from the plunge of each orebody. 

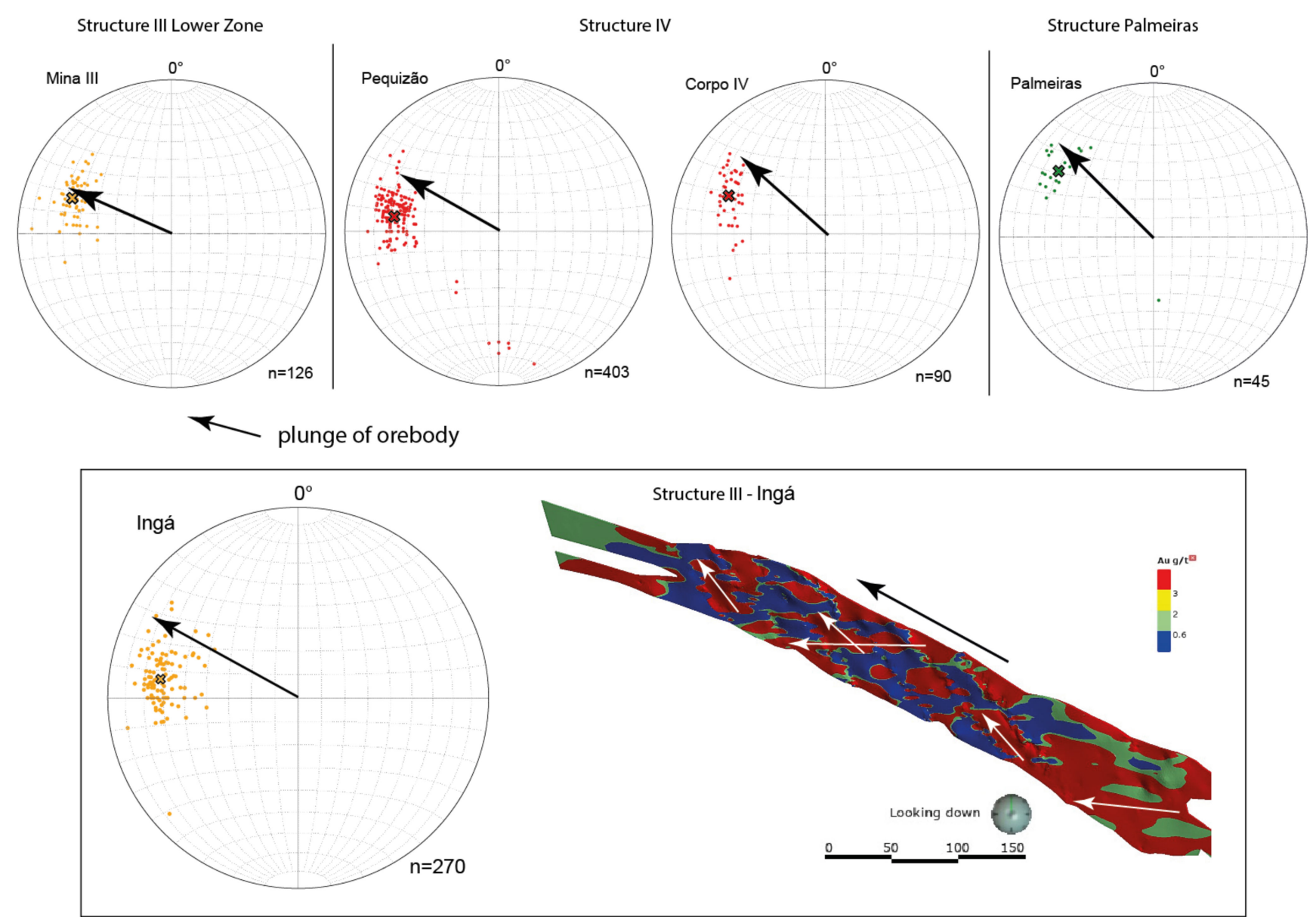

Figure 9. Stereoplots of linear structural data distribution within presented orebodies. Lineations and Fisher mean trend and plunge (cross) in stereoplots are color-coded as follows: Structure III Lower Zone-yellow, Structure IV-red, Structure Palmeiras-green. Arrows represent the trend and plunge of orebodies (black) and oreshoots (white) as calculated in Leapfrog. The bottom figure shows the result of the modelling of oreshoots within the Ingá orebody.

Leapfrog modelling was carried out on the Ingá orebody to visualize possible deviation between orebody and oreshoot plunges (Figure 9). Data for the model contain exploration and grade control drilling, as well as channel sampling within the NW trending corridors. Gold grades were projected on the orebody wireframe and modelled using prolate anisotropy 3:1:1, parallel to the Fisher mean orientation. The model shows two main trends of W-WNW and NW plunging oreshoots.

\subsection{Structural Control on Mineralization}

Considering the "current structural framework", gold mineralization and associated hydrothermal alteration zones are hosted within the duplex. This indicates that mineralization corresponds to several stacked dilation zones. These are interpreted as second-order thrust faults related to major, shallow dipping first-order detachment faults [2]. Main orebodies along at least four horizons are called "Structures" because the mineralization has been traditionally linked to the $\mathrm{D} 2$ thrusts.

According to the "new structural scheme", gold-bearing sulfides are disseminated within numerous intervals of a focused fluid flow parallel to the penetrative S1 foliation. Sulfides occur predominantly in the carbonaceous schists or they are accumulated within S1 parallel layers and lenses of biotite, pyrrhotite, chalcopyrite and arsenopyrite within strongly altered metabasalts (Figure $6 \mathrm{~b}, \mathrm{c})$. Arsenopyrites show frequently strain shadows growing parallel to the $\mathrm{S} 1$ orientation (Figure $6 \mathrm{c}$ ). Accumulations of free-milling gold are 
usually associated with V1 veins in underground orebodies and occur either on S2 fracture cleavages or in the reactivated surface of V1 veins (Figure 7e).

\section{Hydrothermal Alteration and Gold Mineralization}

Exploration and mining of the gold deposits in the Crixás Greenstone Belts revealed three major styles of mineralization [2]: (1) massive sulfide lenses, (2), quartz veins and (3) disseminated sulfide ores. One or more of these styles of mineralization were observed in all orebodies located in mineralized intervals described below.

The uppermost known mineralized interval occurs along the Structure Palmeiras at the contact between the amphibolites of the Rio Vermelho Formation and the dolomite-rich marbles of the metasedimentary sequence of the Ribeirão das Antas Formation (Figure 10). This interval is characterized by a metasomatized zone composed of carbonate-chlorite schist forming metric intervals, for example in the Palmeiras orebody, which is characterized by massive gold-rich sulfide lenses and disseminated gold. The alteration zone can be divided into outer, intermediate and inner halos [34]. The outer halo consists of schists with abundant chlorite, biotite and minor epidote, whereas the intermediate zone is enriched in white mica with minor chlorite. The inner zone comprises variable proportions of chlorite, garnet, amphibole, magnetite, tourmaline, quartz, carbonate and sulfides (pyrite with minor chalcopyrite and pyrrhotite). Gold particles occur associated with pyrite and filling fractures in magnetite, garnet or amphibole [34].
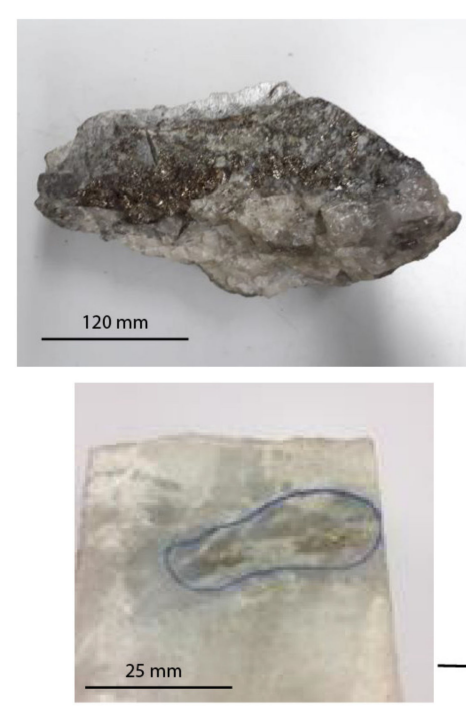

Legend

Metabasalt

Quartz-Chlorite-Carbonate-Sericite Schist

Sericite-Chlorite Schist

Dolomite

V1 laminated quartz vein

Carbonaceus Schist

Felsic Metavolcanics

Quartz-Chlorite-Sericite-Garnet Schist

Metagraywacke

OS1+s2 foliation
S2 foliation
Dissemintated sulphides (Aspy)
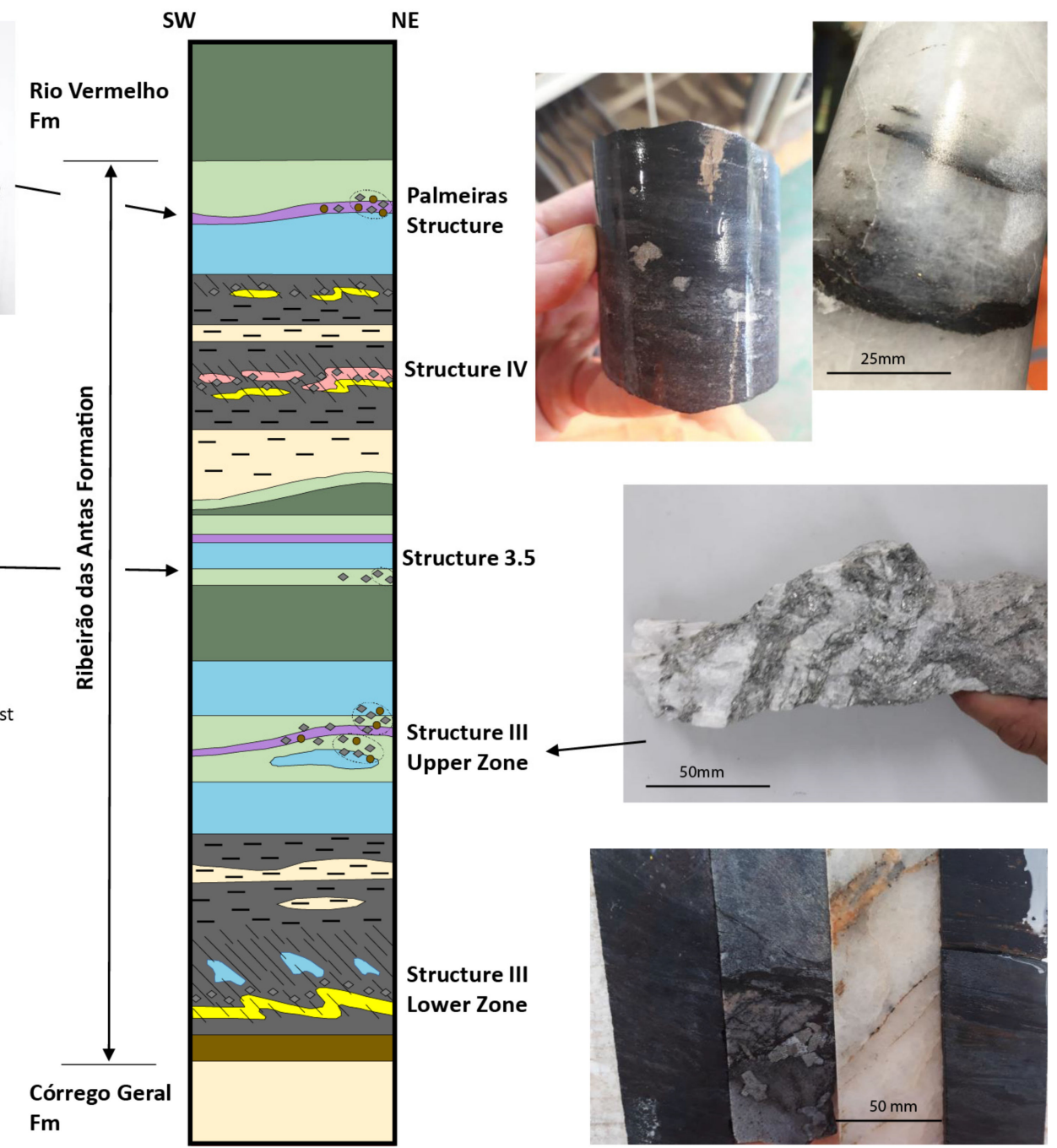

Figure 10. Schematic litho-structural column (not to scale) and examples of mineralization within individual Structures. 
The next mineralized interval, named Structure IV, is located entirely within the Ribeirão das Antas Formation (Figure 10). It is associated with silicified zones that affect both carbonaceous phyllites and siliciclastic rocks. The mineralization is characterized by disseminated gold-rich pyrrhotite/arsenopyrite and gold associated with carbonate quartz-rich veinlets both in the Pequizão orebody [35] and in the Corpo IV orebody [36]. At the Pequizão orebody, the ore is associated with disseminated sulfides, mainly arsenopyrite with minor amount of chalcopyrite and pyrrhotite, hosted in biotite-sericite-quartz schists (Figure 11a-f), preferentially along zones with pervasive silicification.

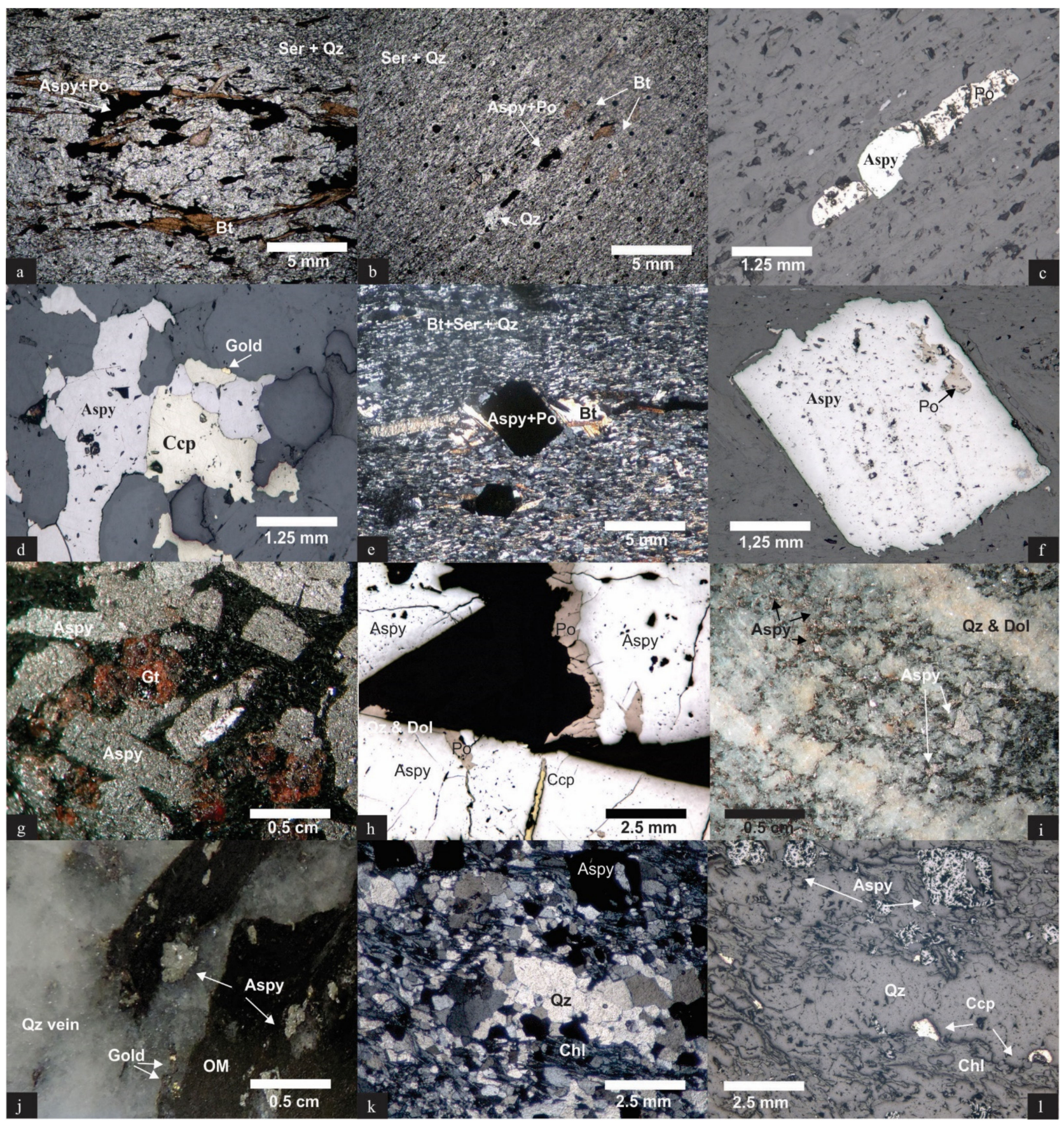

Figure 11. Photomicrographs of different ore styles from the Crixás gold deposit, such as disseminated sulfide (Aspy, Ccp, Po) associated to pervasive silicification at the Pequizão orebody (a-f), massive sulfide (Aspy, Po, Ccp) lenses (g,h) and disseminated sulfide (i) at the Mina III Upper Zone orebody and free gold flakes in quartz-vein (j) and disseminated sulfide $(\mathbf{k}, \mathbf{l})$ at the Ingá orebody. Photomicrographs taken under cross-polarized light $(\mathbf{a}, \mathbf{b}, \mathbf{e}, \mathbf{k})$, natural light $(\mathbf{g}, \mathbf{i}, \mathbf{j})$ and reflected plane-polarized light $(\mathbf{c}, \mathbf{d}, \mathbf{f}, \mathbf{h}, \mathbf{l})$. 
The Structure 3.5 has been defined recently based on a discovery of free-milling gold within dolomites in the southern part of the mine. There is a very little knowledge about its structural links to other mineralized intervals and possible sulfidation horizons.

The mineralization of the Structure III Upper Zone occurs within the Ribeirão das Antas Formation (Figure 10) in the form of massive sulfide lenses. Their occurrence and thickness decrease from the south to the north. The massive lenses consist of arsenopyrite (Figure $11 \mathrm{~g}, \mathrm{~h}$ ) or pyrrhotite, with minor magnetite, ilmenite, bornite and chalcopyrite, and are hosted in dolomite-rich marbles. The lenses are discontinuous and range from $0.5 \mathrm{~m}$ to $2.5 \mathrm{~m}$ in width and $50 \mathrm{~m}$ to $200 \mathrm{~m}$ in length [2,23]. They are surrounded by muscovite schist and chlorite-garnet schist halos $[24,37,38]$ containing a minor amount of disseminated sulfide (Figure 11i). The muscovite schist is composed mostly of muscovite and rare paragonite, with subordinate amounts of chloritoid, garnet, plagioclase and quartz associated with ilmenite, hematite, arsenopyrite, pyrrhotite, pyrite and chalcopyrite $[24,37,38]$. The chlorite-garnet schists are composed of chamosite, garnet, quartz and biotite with subordinate amounts of chloritoid, white mica, grunerite-cummingonite, carbonate, plagioclase and epidote, associated with ilmenite, hematite, arsenopyrite, pyrrhotite and chalcopyrite $[24,37,38]$. The schists capping the massive lenses have been interpreted as hydrothermal products of metabasalts $[1,23]$ or products derived from Al- and Fe-rich metasedimentary rocks [37].

The hydrothermal alteration minerals in the amphibolite host rocks of the Structure III Upper Zone were described in detail by [1,17]. Structures IV and Palmeiras were not yet discovered at the time of the [7] PhD study, and the mineralized horizon was called the Upper Ore Zone. These authors proposed that an increase in hydrothermal ferroan dolomite, oligoclase and muscovite and decrease in chlorite (reacting out to form ferroan dolomite and muscovite) mark the following distinct broad hydrothermal alteration zones (from distal to proximal): (1) chlorite-calcite, (2) chlorite-biotite-ferroan dolomite, (3) biotitemuscovite-ferroan dolomite, and (4) massive ferroan dolomite. Gold is associated with arsenopyrite, pyrrhotite and chalcopyrite and occurs as free-milling gold mostly in V1 laminated quartz veins. Both $[1,17]$ also pointed out that the maximum modal abundance of gold and sulfides appears to be at the margins of, and in, V1 quartz veins within the biotitemuscovite-ferroan dolomite alteration zone near the contact with the massive ferroan dolomite. This suggests that Fe is progressively partitioned into sulfides, with the reaction boundary marking a significant decrease in Fe within muscovite and Fe dolomite, thereby providing Fe for the formation of sulfides [17]. Consequently, the highest abundance of gold relates to the process of carbonatization and related sulfidation of the amphibolite wall-rocks [17].

Mass balance calculations, using the equations of [39] and $\mathrm{Al}$ and $\mathrm{Zr}$ as immobile elements, suggest: (1) an increase in volume relative to the least altered amphibolite, (2) gains of $\mathrm{Ca}$, $\mathrm{Sr}$, and $\mathrm{Ba}$, reflecting the increase in carbonate and phyllosilicates, such as chlorite, biotite and muscovite, (3) gains of $\mathrm{Mg}$, As and $\mathrm{S}$ with the degree of hydrothermal alteration reflecting an increase in Fe carbonate and sulfides, particularly arsenopyrite, (4) significant gains in $\mathrm{Fe}$ in the massive ferroan dolomite zone, (5) loss of $\mathrm{V}$ and $\mathrm{Cu}$ in the chlorite-calcite and chlorite-biotite-ferroan dolomite zone but gains in the biotitemuscovite-ferroan dolomite zone, and (6) distinct loss in $\mathrm{Na}, \mathrm{Ni}, \mathrm{Co}$ and $\mathrm{Zn}$ in all alteration zones [17]. Mineral equilibria assemblages, including the appearance of hydrothermal oligoclase, suggest hydrothermal alteration temperatures in the wallrocks of $440{ }^{\circ} \mathrm{C}$ to $480^{\circ} \mathrm{C}[17]$.

The last mineralized interval is named the Structure III Lower Zone. It is related to laminated quartz veins ( $0.5 \mathrm{~m}$ to $5 \mathrm{~m}$ thick) and surrounding carbonaceous phyllite, such as those from the Mina III Lower Zone, Mina Nova and Ingá orebodies. The mineralization is located above the contact between the Ribeirão das Antas Formation in the hangingwall and the monotonous siliciclastic sequence of the Córrego Geral Formation in the footwall (Figure 10). It is associated with disseminated arsenopyrite and pyrrhotite within hydrothermal halos in carbonaceous schists, and fine flakes $(5 \mu \mathrm{m}$ to $10 \mu \mathrm{m})$ of free-milling 
gold in quartz veins (Figure 11j; [2,23,40]. Disseminated sulfides, such as arsenopyrite and minor chalcopyrite, also occur in chlorite-quartz schists, where silica is abundant (Figure 11k,1), at the contact with the monotonous upper metagraywacke sequences of the Córrego Geral Formation.

\section{Relative and Absolute Timing (Geochronology) of Host Rocks and Gold Mineralization}

The first geochronological data for the Crixás Group were provided by Sm-Nd and $\mathrm{Pb}-\mathrm{Pb}$ isochron ages yielding $2825 \pm 98 \mathrm{Ma}$ and $2728 \pm 140 \mathrm{Ma}$ for the metakomatiites [41]. Later, in ref [24] suggested $2998 \pm 70$ Ma for both komatiites and metabasalts, based on $\mathrm{Sm}-\mathrm{Nd}$ whole-rock analyses. They also interpreted that the metasedimentary sequences of the Upper Subgroup are Proterozoic, supported by $2.3 \mathrm{Ga}$ to $2.5 \mathrm{Ga}$ Nd $\mathrm{T}_{\mathrm{DM}}$ model ages obtained for schists and dolomite-rich marbles [24] of the Ribeirão das Antas Formation. The U-Pb ages of the detrital zircons from meta-graywackes of the Ribeirão das Antas and Córrego Geral formations showed that there is almost a single peak population indicating Rhyacian age $[2,4,42]$ with a subordinate contribution of Archean zircons (Table 2; [2,4]). Positive $\delta^{13} \mathrm{C}(+5.3 \%$ to $+14 \%$ - PDB) in the dolomite-rich marbles [37,43] of the Ribeirão das Antas Formation was considered as additional evidence of a Rhyacian age of the deposition of the formation [3]. The unusual positive anomaly is similar to that described for the Lomagundi Event, characterized by an extraordinarily positive carbon isotope excursion with an enrichment of ${ }^{13} \mathrm{C}$ in carbonates globally that occurred ca. 2.3-2.1 Ga [44-46].

Table 2. Summary of geochronological results. ${ }^{*}$ positive $\delta^{13} \mathrm{C}$ anomalous values of $+5.3 \%$ o to $+14 \%$ o (PDB) interpreted as related to the worldwide Lomagundi Event. ${ }^{* *}$ age from a mixture of metakomatiite and metabasalt samples results. WR—whole rock, aspy—arsenopyrite, amph—amphibole, bt—biotite, cld—chloritoid, ms—muscovite, grt—garnet.

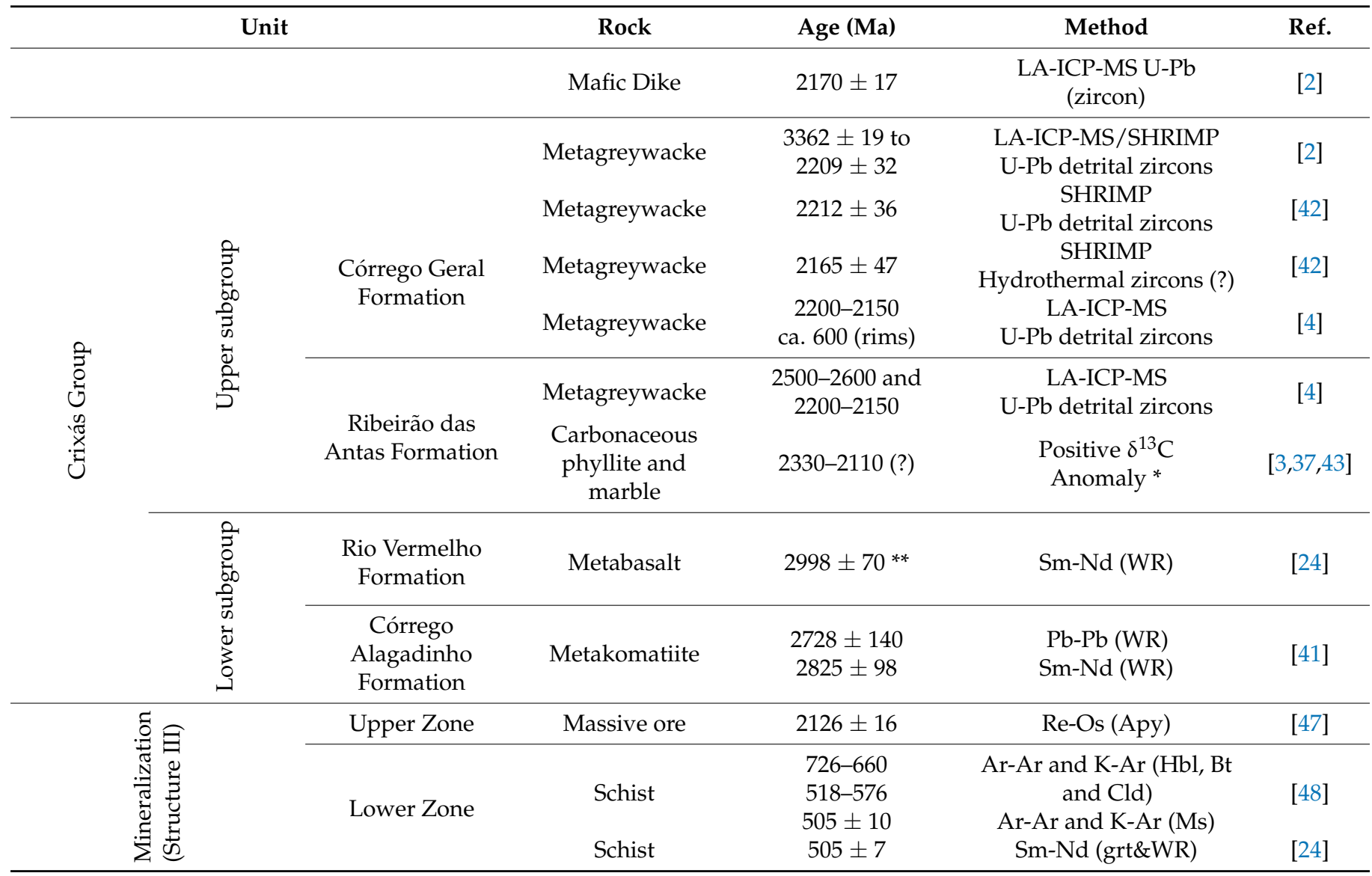

The age of gold mineralization was first suggested to be Archean in view of the general characteristics of the greenstone belt and the presence of meta-komatiites in the 
basal section of the Crixás Group [7,49]. Later, a Neoproterozoic age for gold mineralization, related to the Brasiliano Orogeny, was discussed, and was largely based on the relative timing of some structural arguments and metamorphic events [1]. The first attempt to date mineralization was conducted by [38], followed by [37,48] using K-Ar and Ar-Ar methods in variable types of hydrothermally altered schists located within mineralized intervals of the Mina III orebody. All results presented by these authors point to a Neoproterozoic age for gold mineralization. Ages of 726-660 Ma and 518-576 Ma were obtained from amphibole porphyroblasts and from biotite and chloritoid porphyroblasts, respectively, but both were related to excess argon [48]. A $500 \mathrm{Ma}$ age obtained from muscovite and biotite, related to a post-metamorphic/hydrothermal peak, were interpreted as the age of the ore [48]. Later, a Sm-Nd composite isochron (garnet and whole-rock) yielded an age of $505 \pm 7 \mathrm{Ma}$ and was interpreted as the age of gold mineralization [24]. However, the age of gold mineralization is still considered equivocal due to the issue of isotopic resetting in the K-Ar and Ar-Ar system during the Brasiliano Orogeny. In their study, [42] obtained an age of $2165 \pm 47 \mathrm{Ma}$ (SHRIMP U-Pb on hydrothermal zircons) from hydrothermally altered rocks in the Structure III Lower Zone. Whereas, [2] considered the mineralization restricted in time due to the maximum depositional age of the metasedimentary sequence (ca. $2200 \mathrm{Ma}$, U-Pb LA-ICP-MS and SHRIMP, detrital zircon) and the age of a mafic dike (ca. $2170 \pm 17 \mathrm{Ma}$ ) that crosscut the ore intervals suggesting that deformation, metamorphism and mineralization occurred during approximately $30 \mathrm{Myr}$ to $40 \mathrm{Myr}$ within the Rhyacian. However, the ages of both mafic dike [50] and the possible hydrothermal zircons [42] are not accurate. They were obtained after calculating the regression line (upper intercept age) based on few results, and the former was also recently reconsidered as derived from possible xenocrysts [3]. More recently, an arsenopyrite Re-Os isochron age from massive sulfide ore in the Structure III Upper Zone yielded $2126 \pm 16$ Ma [47], supporting that at least part of the mineralization is in fact constrained to the Rhyacian. Recently, [4] compared detrital zircons between metagraywackes of the mineralized Ribeirão das Antas Formation and the barren Córrego Geral Formation. The results revealed a very consistent, nearly unimodal, Paleoproterozoic age for the provenance ranging from $2200 \mathrm{Ma}$ to $2150 \mathrm{Ma}$, with a major age peak at 2159-2170 Ma. Neoproterozoic well-developed overgrowths were found only on detrital zircons from the barren metagreywackes of the Córrego Geral Formation. The ages of the overgrowth margins have not provided concordant results, owing mainly to high common lead, but were interpreted as consistent with a partial reset around $600 \mathrm{Ma}[4]$.

\section{Hydrothermal Fluids}

Fluid inclusion studies were carried out on rocks from the Structure III Lower and Upper Zones [36,37,51] and Structure IV [36]. The following summary of the fluid inclusion data and interpretations are taken from these sources.

In [51], a summary of fluid inclusions from massive sulfide in the Structure III Upper Zone and V1 laminated quartz veins in the Structure III Lower Zone is provided. These authors concluded that both mineralization styles are characterized by the same fluid inclusions: (1) multiphase $\mathrm{H}_{2} \mathrm{O}-\mathrm{NaCl}-\mathrm{CO}_{2}-\mathrm{CH}_{4}-\mathrm{N}_{2}$ inclusions with the aqueous phase locally characterized by halite daughter crystals, (2) monophase $\mathrm{CO}_{2}-\mathrm{CH}_{4}-\mathrm{N}_{2}$, (3) two phase $\mathrm{H}_{2} \mathrm{O}-\mathrm{NaCl}-\mathrm{CO}_{2}-\mathrm{CH}_{4}-\mathrm{N}_{2}$, and (4) mono and two phase $\mathrm{H}_{2} \mathrm{O}-\mathrm{NaCl}$. However, [51] noticed that the halite bearing aqueous inclusions are much less abundant in the massive sulfide lenses than in the V1 quartz veins. Various lines of evidence-such as, for example, liquid- and vapour-rich aqueous-carbonic, carbonic and undersaturated aqueous fluid inclusions all trapped in the same groups or clusters and displaying similar total homogenization temperatures within different fluid inclusion types-suggest that those fluids were heterogeneously trapped during phase immiscibility between $375{ }^{\circ} \mathrm{C}$ and $475{ }^{\circ} \mathrm{C}$ and $1.5 \mathrm{kbars}$ and $3.3 \mathrm{kbars}$ in massive sulfide lenses, and between $375^{\circ} \mathrm{C}$ and $525^{\circ} \mathrm{C}$ and 1.0 kbars to 3.7 kbars in the V1 quartz veins. The saturated aqueous-carbonic fluid inclusions and the methane- and nitrogen-rich fluid inclusions are interpreted as trapped 
as a consequence of strong lithological control, such as fluid-rock reactions with organic matter in the carbonaceous rocks. Both of these fluid systems are interpreted as trapped at the same time, based on their similar homogenization temperature. There is very limited or no evidence for fluid mixing between these two fluid systems. In the Mina Nova orebody, [37] described the same fluids in the disseminated mineralization style of the Structure III Lower Zone, as documented in the Mina III orebody, and trapping conditions between $400{ }^{\circ} \mathrm{C}$ and $525^{\circ} \mathrm{C}$ and 1.4 kbars and $3.7 \mathrm{kbars}$.

Fluid inclusion petrography and microthermometry were performed on various samples from the Structure IV orebody [36], including: (1) quartz-pyrrhotite-gold veinlets parallel to S1 ( 0.1 cm in width); (2) V1 laminated quartz veins; (3) apatite within hydrothermal alteration zone in equilibrium with pyrrhotite and gold; (4) V2 quartz tension gashes (2-20 cm in width) related to a strong D2 stretching lineation; and (5) V3 quartzsiderite veins spatially associated to F2 folding of V1 laminated quartz veins.

Detailed fluid inclusion petrography revealed the following primary and pseudosecondary fluid inclusion assemblages: (1) $\mathrm{H}_{2} \mathrm{O}-\mathrm{NaCl}-\mathrm{CO}_{2}$, (2) $\mathrm{CO}_{2} \pm \mathrm{H}_{2} \mathrm{O} \pm \mathrm{CH}_{4}$, and (3) $\mathrm{H}_{2} \mathrm{O}-\mathrm{NaCl}$. Fluid inclusion assemblages trapped in veins related to the D2 event include: (1) $\mathrm{H}_{2} \mathrm{O}-\mathrm{NaCl}-\mathrm{CO}_{2} \pm \mathrm{CH}_{4}$ ，(2) $\mathrm{CO}_{2} \pm \mathrm{H}_{2} \mathrm{O} \pm \mathrm{CH}_{4}$, and (3) $\mathrm{H}_{2} \mathrm{O}-\mathrm{NaCl}$. Fluid inclusion assemblages related to the $\mathrm{D} 2$ event contain daughter crystals of unknown origin. The results revealed that the hydrothermal fluids trapped during the D1 and D2 events were largely of the same composition. There were low ( 1 to 7 eq. $\mathrm{wt} \% \mathrm{NaCl}$ ) and medium to high salinity (8-19 eq.wt\% $\mathrm{NaCl}$ ) fluids circulating through the quartz-carbonate vein system. The carbonic phase contains various amounts of $\mathrm{CH}_{4}$ (up to 40 mole\%) and traces of $\mathrm{N}_{2}$. The D1 event contained quartz veins with daughter crystal bearing aqueous inclusions, indicating a slightly more saline fluid when compared to fluids trapped during the D2 event. There is evidence for phase immiscibility during the trapping of fluid inclusions in veins related to the D1 event based on liquid- and vapour-rich inclusions trapped in the same trail and/or cluster and homogenizing into the respective liquid and vapour phases. Adopting the new structural scheme, trapping temperatures during the D1 event was largely between $300^{\circ} \mathrm{C}$ and $450^{\circ} \mathrm{C}$. The minimum trapping temperatures for fluids during the D2 were between $250{ }^{\circ} \mathrm{C}$ and $370^{\circ} \mathrm{C}$, and thus were slightly lower when compared to the D1 event.

In summary, fluids related to the D1 deformation event indicate a possible decrease in trapping temperatures upwards from the Structure III Lower Zone $\left(375-525^{\circ} \mathrm{C}\right)$, then Structure III Upper Zone $\left(375-475^{\circ} \mathrm{C}\right)$ up to the Structure IV $\left(300-450{ }^{\circ} \mathrm{C}\right)$. Additionally, fluids in veins within $\mathrm{D} 2$ related structures show the lowermost trapping temperature of $250-370{ }^{\circ} \mathrm{C}$.

\section{Discussion}

\subsection{Origin of High-Grade Oreshoots}

Variations in the plunge of individual orebodies have puzzled exploration geologists over the years. The low angle orebody variation between NW and WNW to W were addressed in the confidential work of consultants but were never presented and discussed in the scientific literature. This problem has been fuelled by problematic and inconsistent identification of L1 versus L2 stretching lineations on reactivated S1 foliation planes. Over the years of exploration and the collection of structural data, it has been recognized that there are oreshoots within some orebodies that plunge parallel to the observed lineation, but oblique to the orebody itself (Figure 9). A synthesis of described plunges, structural data and the nature of gold occurrences (free milling gold versus gold in sulfides) appears to provide an answer. The most endowed orebodies are located in the Structure III Lower Zone and are significantly affected by D2 folding and a strong L2 stretching lineation trending to the W-WNW. Interestingly, areas of F2 folding show a high modal abundance of free-milling gold (e.g., in the Structure III Lower Zone) compared to those with dominantly gold-bearing sulfides and only a weak or no D2 overprint (e.g., in the Palmeiras structure). Considering the example of the Palmeiras orebody, it appears that the NW plunge of the 
orebody characterizes the D1 deformation event. The Mina III orebody also shows the parallelism between plunge of orebody and measured linear data, but the orebodies are plunging to the WNW. This plunge is attributed to the $\mathrm{D} 2$ deformation event and refolding associated with the strong stretching lineation L2. The Pequizaõ, Ingá and Corpo IV orebodies show the angular relationship between the orebody plunge and linear structural data (Figure 9). Using the example of the Ingá orebody, we have demonstrated that there are two ore shoot plunges. The first oreshoot plunge to the NW is considered structurally to be early and related to the D1 deformation. The second oreshoot plunge to the W-WNW is considered to be structurally late and related to the D2 deformation. It seems that the 'bulk plunge' of these orebodies is a combination of both plunges defined by D1 and D2 deformation events. Consequently, it leaves a notable deviation between 'bulk orebody plunge' and the Fisher mean of linear structural data (Figure 9).

More focused structural studies need to be carried out to better support this explanation via targeted sampling of mineralized intervals within individual oreshoots. In other words, detailed petrology and mineralogy of ore samples is required to demonstrate the link between ore shoot plunge and ore composition (i.e., 'free milling' versus refractory gold). A similar situation has been demonstrated in the Obuasi orogenic gold deposit in Ghana [52]. At Obuasi, lattice-bound gold in arsenopyrite occupies sheeted orebodies neighbouring laminated quartz veins and carbonaceous rocks. 'Free milling' gold is linked to 'late' folding of the sheeted orebodies and the direction of the late fold axes shows parallelism to the high-grade oreshoots. These relationships raise the question about the possible remobilization of gold from sulfides and, consequently, its precipitation as 'free' gold [53].

\subsection{Critical Assessment of the Current Structural Framework}

There are several observations that open space for a discussion and possible reinterpretation of the current structural framework (Table 1). The D1 deformation is linked to the bedding parallel shearing. It is presented separately from the main D2 deformation event, which is linked to the overturning of the stratigraphy [2,3]. The flexural slip mechanism of folding usually leads to bedding parallel foliation, which could be misinterpreted as a separate deformation event. Therefore, D1 and D2 events, as currently defined by the structural framework [2] may be interpreted as one, progressive D1 deformation event.

The D2 deformation in the current structural framework is commonly associated with thrusting and thin-skinned tectonics with movement top to the NE, F2 refolding, gold mineralization, and overturning of the stratigraphy. It is an attractive model linking thrusting and gold mineralization that is described elsewhere (e.g., [54]), but it has been challenging to follow it in the Crixás Greenstone Belt. Supporting structural data and kinematic analysis, including robust kinematic indicators, are not provided in the literature, resulting in the model being largely conceptual. For example, Figure 4 in [2] shows what was presented as D1 folds refolded by D2 and crosscut by the mineralized detachment interval (Figure 12a). Re-interpretation of the same figure indicates strain partitioning during a single F1 folding of bedding into a high shear strain $\mathrm{S} 1$ axial planar domain, which hosts the orebody, and a F1 folded domain with S-shape parasitic folds (Figure 12b,c). A range of structures that develop during $\mathrm{F} 1$ folding may provide a reasonable alternative to the thrust zone model (Figure 12d). The flexural slip mechanism of folding is usually linked to the formation of parasitic second- and higher-order folds whereas non-coaxial shearing takes place on axial planar cleavages (Figure 12d; i.e., [55,56]). The S1 development may be linked to a localized increase in strain rate that, together with high fluid pressure, facilitates brittle deformation and fluid flow (e.g., [57,58]). This is demonstrated in V1 laminated quartz veins, sulfide lenses and disseminated sulfides with strain shadows parallel to the S1 foliation (Figure 6c). Apparent duplex structures may develop this way in the overturned limb of the stratigraphy that resembles thrust faults geometrically as well as kinematically (Figure 12d). Additionally, zones of dominant parasitic folds alternate with zones of strong shearing and fluid flow (Figure 12d). 

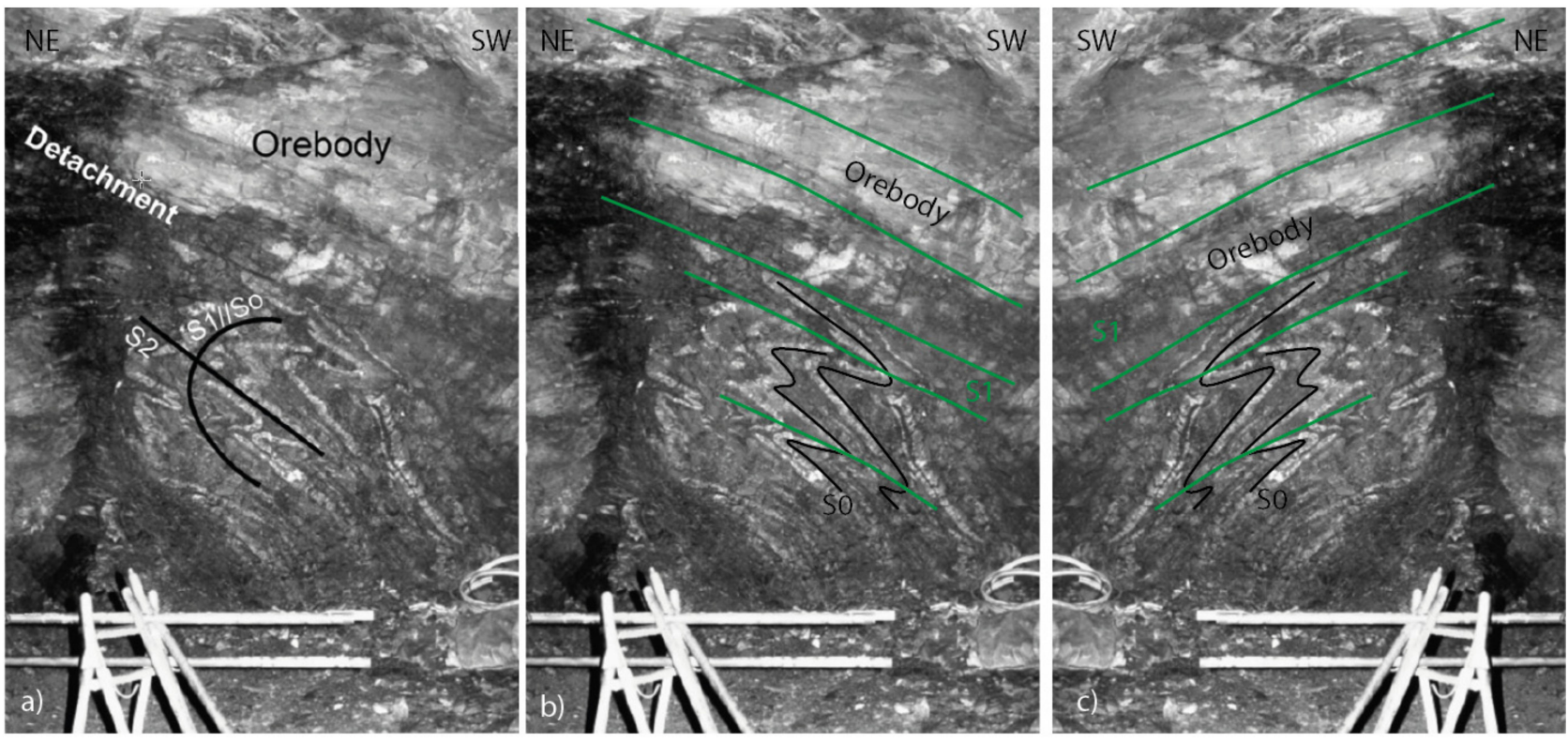

SW
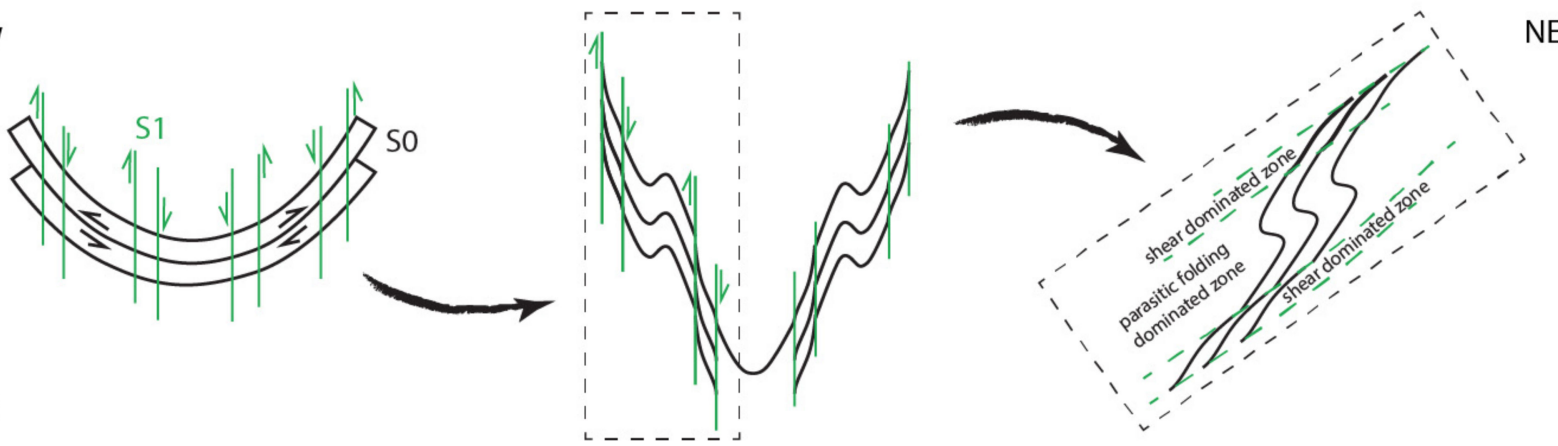

d)

Figure 12. Re-interpretation of the current tectonic model. (a) Adapted with permission from [2] (Elsevier, 10 May 2021); (b) A new interpretation of the same photograph; (c) Rotation of the original picture and the new interpretation to the commonly used orientation looking NW; (d) A conceptual tectonic sketch is showing the development of parasitic folds and axial planar foliation $\mathrm{S} 1$ as well as subsequent rotation to the final position.

The D3 deformation in the current structural framework is related to the thrusting of the Mara Rosa magmatic arc to the south, gold remobilization and the reshaping of orebodies. Recumbent folding of the V1 laminated quartz veins in the footwall greenstone belt, that are linked to this event (F3 folds in [2] and F2 folds in this work), are localized only within competent lithologies embedded within incompetent rocks. The double dip of fold axial planes to the W and NE (Figure 7) indicates that the shape of NW-SE trending Rio Vermelho antiform (Figure 2) controls current geometry of these folds. These folds show a systematic S-shape regardless of the dip direction of fold axial planes that is consistent with F1 parasitic folding. Finally, there does not seem to be a gradient in the folding intensity from the Mara Rosa magmatic arc contact down to its footwall.

Another aspect of the tectonics worth discussing is related to the peak metamorphic assemblages that are interpreted to be overprinted by thrust related foliation ([13]; S2, according to [2]). Foliated amphibolite is metamorphosed to epidote-amphibolite facies conditions at temperatures of $400-500{ }^{\circ} \mathrm{C}$ and pressures of $0.3-0.5 \mathrm{GPa}$ [7]. This is compatible with a ca. $30^{\circ} \mathrm{C}$ per kilometre thermal gradient that is typical for orogenic zones older than $1000 \mathrm{Ma}$ (e.g., [59]). These conditions may indicate either progressive burial during the formation of the Crixás Greenstone Belt synclinorium or metamorphism and high heat flow during formation of the Rhyacian basin. However, more metamorphic studies are needed to better constrain potential metamorphic gradients and zoning across the belt. 


\subsection{A New Structural Scheme}

The new structural data presented in this manuscript, combined with a review of the lithostratigraphic, hydrothermal alteration and mineralization data sets, show several lines of evidence which challenge the current structural framework. They allow for proposing an alternative scenario for the structural evolution and associated gold mineralization in the Crixás Greenstone Belt during the Paleoproterozoic time (Figure 13). Detrital zircons from the Ribeirão das Antas and Córrego Geral formations (Table 2 and references therein) suggest that the crustal evolution commenced with extensional tectonics and the deposition of a Rhyacian basin at ca. 2150-2200 Ma. In their study, [3] suggested that the Rhyacian basin (Upper Subgroup) non-conformably overlies the Archean portion (Lower Subgroup) of the Crixás Greenstone Belt. Unquestionably, there is ca. $800 \mathrm{Myr}$ difference between both subgroups of the basin (Table 2, [3]). However, all lithostratigraphic columns presented in the literature to date show a distinct lack of an angular relationship between volcanic layering in the Lower Subgroup and bedding in the Upper Subgroup (e.g., [2-4]). It is very difficult, and likely impossible, to resolve this question of original angular relationship due to the strong Paleoproterozoic orogenic overprint. Therefore, there is no geological evidence that the sagduction, as described by [3], actually took place during the Archean. Consequently, the boundary between the Rio Vermelho and Ribeirão das Antas formations is considered here to be a major extensional fault zone (Figure 13a).

a)

Formation of Rhyacian basin

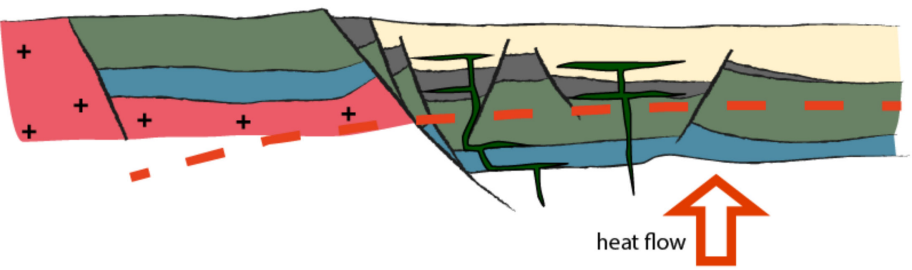

b) D1: Sagduction or accretion? Formation of subvertical S1 foliation, gold mineralization and V1 laminated quartz veins

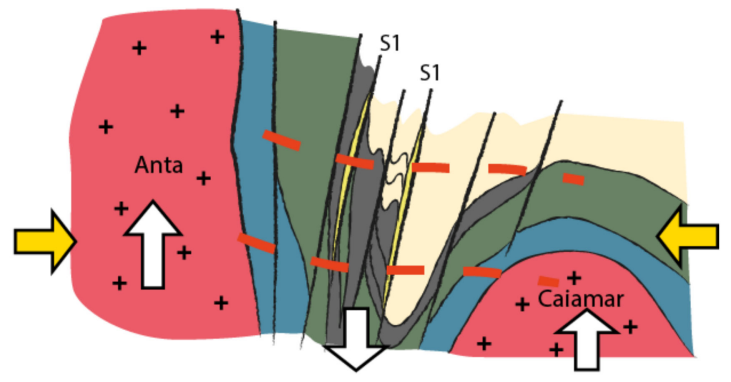
surfaces and formation of localised S2 axial planar cleavage
$\mathrm{S} 1 \| \mathrm{S} 2$

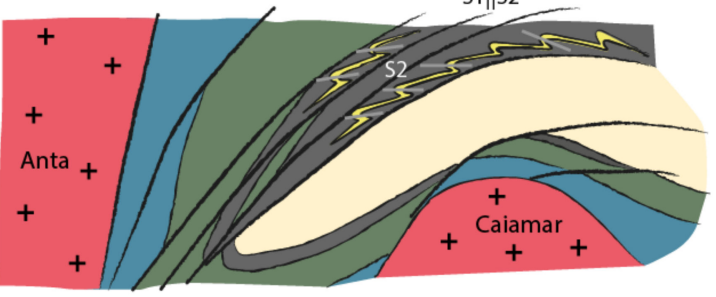

S1

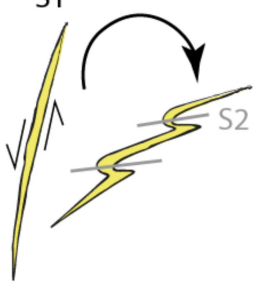

Чூ sagduction
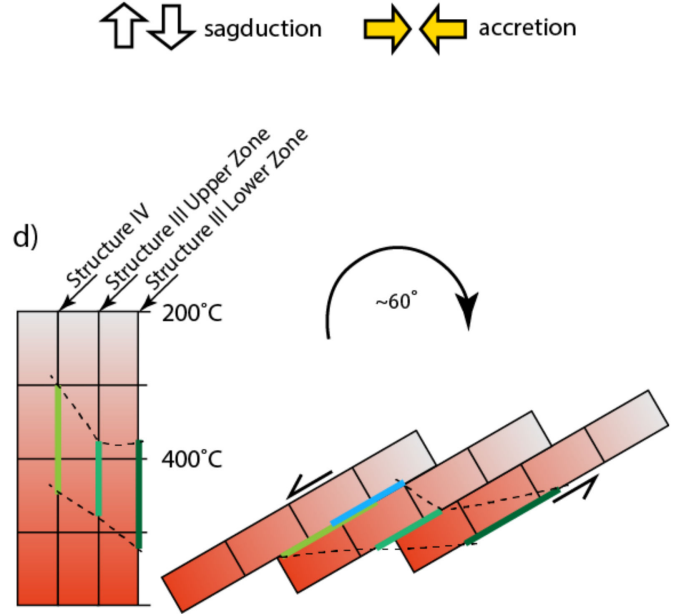

Figure 13. (a) Not-to-scale sketch of the tectonic setting of the Rhyacian basin before the Paleoproterozoic Orogeny; (b) Sagduction and the formation of sulfide-rich orebodies and laminated quartz veins (D1); (c) Development of high-grade ore shoots via localized F2 folding, tilting and overturning of the Crixás Greenstone Belt stratigraphy (D2); (d) Temperature ranges of trapped hydrothermal fluids during D1 (shades of green) are projected on the individual 'Structures' (left). The bookshelf sliding model of tilted D1 geotherm and temperature range of trapped hydrothermal fluid during D2 (blue) explains the recent juxtaposition of the trapping temperatures. 
The extensional tectonic environment is capable of dismembering footwall basalts and juxtaposing slivers of them into the Rhyacian basin potentially already during basin formation. This is compatible with the identification of metamorphosed metabasalts (amphibolites) as a key host lithology for gold mineralization, besides carbonaceous shales, within the Ribeirão das Antas Formation [13]. It is noteworthy that reactivated extensional fault zones are, in many places around the world, interpreted to be the 'fluid highway' for syntectonic hydrothermal fluids, locally containing a significant amount of metals (e.g., [60]).

The current knowledge of the lithostratigraphy and geochronology reviewed above, confirms that the lithostratigraphy is overturned. The overturning of the stratigraphy is interpreted as starting during the formation of the regional-scale synclinorium, S1 foliation and folding of bedding leading to parasitic S-folds within the overturned limb (Figure 13B). Localized percolation of the mineralizing fluids parallel to the S1 foliation and F1 fold axes follows the establishment of the D1 structural framework. A tectonic scenario responsible for the D1 deformation may involve a sagduction process, meaning the sinking of heavy mafic oceanic crust with overlying sedimentary sequences and diapirism of light, felsic TTG domes (cf. [61]), during the Rhyacian. Sagduction triggered by gravitational instability is certainly an efficient process for Archean tectonics and is supported by geological and numerical models (e.g., [62,63]). It has been proposed as a reasonable orogenic process in the Paleoproterozoic, including examples from the West African craton $[64,65]$. An alternative tectonic scenario to the sagduction involves an inversion and an accretion of the rifted domain in a form of the regional-scale synclinorium that partly exist in the current tectonic framework [2-4].

There are rheological constraints to sagduction as well as accretion that need to be discussed here. Existing geochronology shows a lack of Paleoproterozoic overprint of Archean zircons from the Anta and Caiamar complexes [10]. This indicates that the complexes were indeed below the isotopic stability of the U-Pb-Th system in zircon and below partial melting temperature, which makes the diapiric rise required by sagduction difficult. However, there are investigations that describe: (a) shear zones within TTG complexes operating between 2150-2000 Ma, and (b) Paleoproterozoic granite intrusive in the neighbouring Pilar de Goiás Greenstone Belt (2145 $\pm 12 \mathrm{Ma})$ that have not been considered in the frame of the regional tectonics [10]. Another rheological constraint relates to the rifted domain of the Rhyacian basin. It is supposed to be weaker compared to the rift shoulders (TTG complexes) due to mantle upwelling and high heat flow, as documented by mafic dikes [50]. However, this is only true if there is no significant period of cooling of the rifted domain before an accretion [66]. Existing geochronology shows ca. 40-50 Myr between intrusion of mafic dikes (2170 $\pm 17 \mathrm{Ma}$, [2]) and hydrothermal alteration and mineralization, documented as parallel to the $\mathrm{S} 1$ foliation (2126 $\pm 16 \mathrm{Ma}$, [47]). Whether it is an Archean (sagduction) or Phanerozoic (accretion) style of tectonics, or even a combination of both, represents an interesting topic for further studies that should involve detailed regional-scale structural mapping and thermo-mechanical modelling.

The currently documented, westerly dipping geometry, of the Crixás synclinorium has been traditionally linked to the NE-thrusting [2-4] accompanying the accretion. The fluid inclusion data presented above indicate that hydrothermal fluids of the same composition were circulated during both early and late deformation events (D1 and D2 as reviewed here). The temperature of the fluids trapped in the veins associated with D1 structures decreases from the bottom to the top of the rock sequence, which indicates normal rather than reverse movement on the reactivated S1 foliation (Figure 13D). Additionally, both F1 and F2 folding produce systematic S-folds, and it is likely that they represent one continuous deformation event affecting the Archean ultramafic and mafic crust and the overlying Rhyacian basin. The development of rheologically strong and competent, laminated V1 quartz veins during D1, compared to the incompetent carbonaceous schists, makes the former prone to parasitic folding during D2 deformation. These observations indicate an E-verging tilting (Figure 13) of the steepened stratigraphy and subvertical S1 foliation over 
an attenuated and NW-plunging Caiamar TTG complex at depth (Figure 1). The tilting of the rock sequence resulted in localized parasitic F2 folding, synchronous bookshelf sliding (normal movement) and reactivation of the S1 foliation (Figure 13d). This 'sagduction and tilting model' is in a clear contradiction to the 'accretion and thrusting model' proposed in the current structural framework (e.g., [2]). Additional stratigraphic and structural work (e.g., kinematic analysis) is necessary to test either model further. In addition, a careful comparison and synthesis of structural data from TTG domes as well as numerical modelling of relevant structural processes are warranted, particularly considering rapid improvements in the coding of the thermomechanical evolution of the lithosphere (e.g., [63]).

Further attention is also required to unmineralized mafic dikes that crosscut lithologies and hydrothermal alteration [50]. These dikes were dated at $2170 \pm 17 \mathrm{Ma}$ (Table 2) from zircon xenocrysts (U-Pb SHRIMP [3]), but there is a lack of accuracy. They are foliated at least along their margins, and microstructural evidence shows dynamic recrystallization of magmatic plagioclase (Figure 5B,C in [50]). A strain partitioning into weak and strongly deformed carbonaceous schists may explain limited strain in mafic dikes, and consequently their pre-mineralization origin. New geochronology, petrology and structural data would help to better understand their tectonic history and the time gap between the Rhyacian rift opening and inversion (mineralization) that is critical for thermo-mechanical modelling.

\section{Conclusions}

Compilation of the deposit-scale geological data shows significant advances in lithostratigraphy and geochronology of the Crixás greenstone belt over the last decade. (e.g., [3,4]). Mineralization occurs within the stratigraphic interval of Paleoproterozoic carbonaceous schists of the Ribeirão das Antas Formation with tectonically juxtaposed bodies of Archean amphibolites from the Rio Vermelho Formation. There are several mineralized horizons that occur within the overturned limbs of the regional-scale synclinorium. Pyrrhotite and arsenopyrite represent dominant Au-bearing sulfides.

A review of the deposit-scale structural data, in addition to new interpretations presented in this work, attempted to explain the origin of ore shoots in the Crixás gold deposit on examples from Mina III, Ingá, Corpo IV, Pequizão and Palmeiras. The interpretation of structural data shows that D1 deformation controls the precipitation of Au-rich sulfides and the formation of NW trending orebodies. The D2 event of localized F2 folding and strong L2 stretching lineations created oreshoots trending W-WNW within distinct orebodies. It appears that the $\mathrm{D} 2$ deformation is associated with the precipitation of native $\mathrm{Au}$. However, further work focused on detailed structurally-controlled mineralogy is required to constrain this model.

The review of existing and new geological data from the Crixás gold deposit was used to propose an alternative tectonic scenario during gold mineralization in Rhyacian times. It has been argued that the sulfides-dominated (pyrrhotite, arsenopyrite) mineralization is associated with the development of S1 laminated quartz veins and dominant $\mathrm{S} 1$ foliation. It is proposed that this is coeval with the gravity-driven process of sagduction and formation of regional-scale synform within the Archean oceanic crust and overlying Paleoproterozoic metasedimentary rocks. Differential diapiric rise of TTG domes at both sides of the synform led to the tilting of the S1 foliation, development of localized secondary F2 parasitic folds and a bookshelf sliding-type normal reactivation of the S1 foliation. Further work on kinematic structural analysis across scales and rock types and metamorphic petrology are necessary to substantiate either this or the current thrusting model (e.g., [2-4]).

Author Contributions: Conceptualization, S.U., S.H. and J.C.M.; methodology, whole team; validation, S.U., F.L.A.R.F. and J.E.F.R.; formal analysis, S.H., J.C.M. and J.C.F.; investigation, S.U., J.C.M., F.L.A.R.F., J.E.F.R., J.C.F. and K.P.; resources, J.C.M., F.L.A.R.F., J.E.F.R., J.C.F. and K.P.; data curation, S.U. and J.C.M.; writing-original draft preparation, S.U.; writing—review and editing, S.U., S.H. and J.C.M.; visualization, S.U., J.C.M., F.L.A.R.F. and J.E.F.R.; supervision, S.H. and J.C.F.; project administration, S.U. and J.C.M.; funding acquisition, J.C.M. All authors have read and agreed to the published version of the manuscript. 
Funding: This research was funded by CNPq (Conselho Nacional de Desenvolvimento Científico e Tecnológico), grant number 309519/2018-7.

Acknowledgments: Mineração Serra Grande S.A. owned by AngloGold Ashanti Brasil is acknowledged for supporting the publication of this review. The authors are especially grateful to past and current leaders and members of the exploration team in Crixás for continuous support, teamwork and dedicated daily exploration work that supplied presented data. Authors are indebted to Renan Guilherme de Souza for preparing the long section. SU acknowledges numerous works of structural consultants, namely Rod Holcombe, Andrew Allibone, Leigh Rankin, Tim Coughlin, Jeff Wilson and Armando Massucato, that provided basis for sketching Figure 5. A thoughtful review of three anonymous reviewers contributed to improved clarity.

Conflicts of Interest: The authors declare no conflict of interest.

\section{References}

1. Thomson, M.L.; Fyfe, W.S. The Crixás gold deposit, Brazil; thrust-related, postpeak metamorphic gold mineralization of possible Brasiliano Cycle age. Econ. Geol. 1990, 85, 928-942. [CrossRef]

2. Jost, H.; Chemale Jr, F.; Dussin, I.A.; Tassinari, C.C.G.; Martins, R. AU-Pb zircon Paleoproterozoic age for the metasedimentary host rocks and gold mineralization of the Crixás greenstone belt, Goiás, Central Brazil. Ore Geol. Rev. 2010, 37, 127-139. [CrossRef]

3. Jost, H.; Apollo, J.F.H.; Weber, W.; Salles, R.d.R.; Marques, J.C.; Massucatto, A.J.; Costa, D.A.; dos Santos, B.A. Stratigraphic update, paleotectonic, paleogeographic, and depositional environments of the Crixás Greenstone Belt, Central Brazil. J. South. Am. Earth Sci. 2019, 96, 102329. [CrossRef]

4. $\quad$ Ferreira, B.F.; Marques, J.C.; Frantz, J.C.; Souza, R.G.d.; Campos, M.P.; Figueiredo, F.L.A.d.R.; Padilha, N.L. Stratigraphy and $\mathrm{U}-\mathrm{Pb}$ detrital zircon provenance, Crixás Greenstone Belt, Goiás-Brasil: Gold-bearing vs barren siliciclastic rocks. J. South. Am. Earth Sci. 2021, 105, 102994. [CrossRef]

5. Magalhães, L. Cinturão de Cisalhamento de Empurrão Córrego Geral/Meia Pataca: Geologia, Deformação, Alteração Hidrotermal e Mineralizações Auríferas Associadas (Crixás, Goiás). Master's Thesis, Universidade de Brasília, Brasília, Brazil, 1991.

6. Queiroz, C. Evolução Tectono-Estrutural dos Terrenos Granito-Greenstone Belt de Crixás, Brasil Central. Ph.D. Thesis, Universidade de Brasília, Brasília, Brazil, 2000.

7. Thomson, M.L. The Crixás Gold Deposit, Brazil: Metamorphism, Metasomatism and Gold Mineralization. Ph.D. Thesis, The University of Western Ontario, London, ON, Canada, 1987.

8. Pimentel, M.M.; Fuck, R.A.; Jost, H.; Ferreira Filho, C.F.; Araújo, S.D. The basement of the Brasília fold belt and the Goiás magmatic arc. Tecton. Evol. S. Am. 2000, 31, 195-229.

9. Pimentel, M.M.; Hollanda, M.H.; Armstrong, R. Shrimp U-Pb age and Sr-Nd isotopes of the Morro do Baú mafic intrusion: Implications for the evolution of the Arenópolis volcano-sedimentary sequence, Goiás Magmatic Arc. An. Acad. Bras. Ciências 2003, 75, 331-339. [CrossRef]

10. Queiroz, C.L.; Jost, H.; da Silva, L.C.; McNaughton, N.J. U-Pb SHRIMP and Sm-Nd geochronology of granite-gneiss complexes and implications for the evolution of the Central Brazil Archean Terrain. J. S. Am. Earth Sci. 2008, 26, 100-124. [CrossRef]

11. Jost, H.; Junior, F.C.; Fuck, R.A.; Dussin, I.A. Uvá complex, the oldest orthogneisses of the Archean-Paleoproterozoic terrane of central Brazil. J. S. Am. Earth Sci. 2013, 47, 201-212. [CrossRef]

12. Kuyumjian, R.M.; de Araújo Filho, J.O. Contrinuição à tectônica do Greenstone belt da Faixa Goiás, Crixás. Rev. Bras. Geociências 1984, 14, 92-96. [CrossRef]

13. Thomson, M. Multiphase deformation and metamorphism of the Crixás greenstone belt, Goiás, Brazil: Evidence from poikiloblast inclusion trails and metamorphic mineral assemblages. J. S. Am. Earth Sci. 1991, 4, 119-130. [CrossRef]

14. Araujo, F.J. Structural Characteristics and Tectonic Evolution of the Pirineus Syntaxis, Central Brazil. Ph.D. Thesis, University of Illinois at Urbana-Champaign, Champaign, IL, USA, 2000.

15. Viana, M.D.G.; Pimentel, M.M.; Whitehouse, M.J.; Fuck, R.A.; Machado, N. O arco magmático de Mara Rosa, Goiás: Geoquímica e geocronologia e suas implicações regionais. Rev. Bras. Geociências 1995, 25, 111-123. [CrossRef]

16. Resende, M.G.; Jost, H.; Osborne, G.A.; Mol, A.G. Stratigraphy of the Goiás and Faina greenstone belts, Central Brazil: A new proposal. Rev. Bras. Geociências 1998, 28, 77-94. [CrossRef]

17. Thomson, M. Wall-rock alteration related to Au mineralization in the low amphibolite facies; Crixás gold mine, Goias, Brazil. Can. Mineral. 1991, 29, 461-480.

18. Pimentel, M.M.; Whitehouse, M.J.; Viana, M.d.G.; Fuck, R.A.; Nuno, M. The Mara Rosa arch in the Tocantins province: Further evidence for neoproterozoic crustal accretion in Central Brazil. Precambrian Res. 1997, 81, 299-310. [CrossRef]

19. Kuyumjian, R.M. Mafic dike swarms of the Goiás massif, central Brazil. Rev. Bras. Geociências 1998, 28, 45-50. [CrossRef]

20. Jost, H.; Oliveira, A.M.d. Stratigraphy of the greenstone belts, Crixás region, Goiás, central Brazil. J. S. Am. Earth Sci. 1991, 4, 201-214. [CrossRef]

21. Jost, H.; Fuck, R.; Brod, J.A.; Dantas, E.L.; Meneses, P.R.; Assad, M.L.L.; Pimentel, M.M.; Blum, M.; Silva, A.M.; Spigolon, A.L.D. Geologia de terrenos Arqueanos e Proterozóicos da região de Crixás-Cedrolina, Goiás. Rev. Bras. Geociências 2001, 31, $315-328$. [CrossRef] 
22. Saboia, L.A.d.; Teixeira, N.A. Ultramafic flows of the Crixás greenstone belt, Goiás-Brazil. Precambrian Res. 1983, 22, 23-40. [CrossRef]

23. Jost, H.; de Tarso Ferro de Oliveira Fortes, P. Gold deposits and occurrences of the Crixás Goldfield, central Brazil. Miner. Depos. 2001, 36, 358-376. [CrossRef]

24. De Tarso Ferro de Oliveira Fortes, P.; Pimentel, M.M.; Santos, R.V.; Junges, S.L. Sm-Nd studies at Mina III gold deposit, Crixás greenstone belt, central Brazil: Implications for the depositional age of the upper metasedimentary rocks and associated Au mineralization. J. S. Am. Earth Sci. 2003, 16, 503-512. [CrossRef]

25. Thomson, M. Petrology of the Crixás gold deposit, Brazil: Evidence for gold associated with hydrothermal alteration subsequent to metamorphism. In Gold '86, an International Symposium on the Geology of Gold Deposits: Proceedings Volume; Gold '86: Toronto, ON, Canada, 1986; pp. 284-296.

26. Sabóia, L. Os greenstone belts de Crixás e Goiás-GO. Boletim de Geociências do Centro-Oeste 1979, 9, 44-72.

27. Kuyumjian, R. Geologia e Mineralizações Auríferas do Greenstone Belt da Faixa Crixás, GO. Master's Thesis, Universidade de Brasília, Brasília, Brazil, 1981.

28. Goscombe, B.D.; Passchier, C.W.; Hand, M. Boudinage classification: End-member boudin types and modified boudin structures. J. Struct. Geol. 2004, 26, 739-763. [CrossRef]

29. Fossen, H. Structural Geology; Cambridge University Press: New York, NY, USA, 2010; p. 463.

30. Bell, T. Deformation partitioning and porphyroblast rotation in meta-morphic rocks: A radical reinterpretation. J. Metamorph. Geol. 1985, 3, 109-118. [CrossRef]

31. Fossen, H.; Cavalcante, G.C.G.; Pinheiro, R.V.L.; Archanjo, C.J. Deformation-progressive or multiphase? J. Struct. Geol. 2019, 125, 82-99. [CrossRef]

32. Queiroz, C.; Alkmim, F.; Kuyumjian, R. Estudo dos lineamentos de relevo da região do Greenstone Belt de Crixás, GO, através de imagens de sensores remotos. Boletim de Geociências do Centro-Oeste 1995, 18, 57-65.

33. Queiroz, C. Caracterização dos Domínios Estruturais e da Arquitetura do Greenstone Belt de Crixás, GO. Master's Thesis, Universidade de Brasília, Brasília, Brazil, 1995.

34. Almeida, B. Mineralização Aurífera, Alteração Hidrotermal e Indicadores Prospectivos do Corpo Palmeiras, Greenstone Belt de Crixás, Goiás. Master's Thesis, Universidade Federal do Rio Grande do Sul, Porto Alegre, Brazil, 2006.

35. Sobiesiak, M.S. Caracterização de Depósito Aurífero no Corpo Pequizão, Crixás-GO; Trabalho e Conclusão de Curso; Universidade Federal do Rio Grande do Sul: Porto Alegre, Brazil, 2011.

36. Petersen Junior, K.J. Estudo das Mineralizações Auríferas do Corpo IV e V da Estrutura IV do Greenstone Belt de Crixás (GO). Ph.D. Thesis, Universidade de São Paulo, São Paulo, Brazil, 2003.

37. De Tarso Ferro de Oliveira Fortes, P. Metalogênese dos Depósitos Auríferos Mina III, Mina Nova e Mina Inglesa, Greenstone Belt de Crixás, GO. Ph.D. Thesis, University of Brasília, Brasília, Brazil, 1996.

38. De Tarso Ferro de Oliveira Fortes, P. Geologia do Depósito Aurífero Mina III, Crixás, Goiás. Master's Thesis, Universidade de Brasília, Brasília, Brazil, 1991.

39. Gresens, R.L. Composition-volume relationships of metasomatism. Chem. Geol. 1967, 2, 47-65. [CrossRef]

40. Castoldi, M.A.S. Geologia e Geoquímica da Zona Inferior do Corpo de Minério Ingá, Distrito Aurífero de Crixás, Goiás, Brasil: Implicações Genéticas e Exploratórias. Master's Thesis, Universidade Federal do Rio Grande do Sul, Porto Alegre, Brazil, 2018.

41. Arndt, N.; Teixeira, N.; White, W. Bizarre geochemistry of komatiites from the Crixás greenstone belt, Brazil. Contrib. Mineral. Petrol. 1989, 101, 187-197. [CrossRef]

42. Tassinari, C.; Jost, H.; Santos, J.; Nutman, A.; Bennell, M. Pb and Nd isotope signatures and SHRIMP U-Pb geochronological evidence of Paleoproterozoic age for Mina III gold mineralization, Crixás District, Central Brazil. In Proceedings of the 5th South American Symposium on Isotope Geology, Punta Del Este, Uruguay, 23-26 April 2006; pp. 527-529.

43. Dix, G.R.; Thomson, M.L.; Longstaffe, F.J.; McNutt, R.H. Systematic decrease of high $\delta 13 \mathrm{C}$ values with burial in late Archaean (2.8 Ga) diagenetic dolomite: Evidence for methanogenesis from the Crixás Greenstone Belt, Brazil. Precambrian Res. 1995, 70 , 253-268. [CrossRef]

44. Bekker, A.; Karhu, J.; Kaufman, A. Carbon isotope record for the onset of the Lomagundi carbon isotope excursion in the Great Lakes area, North America. Precambrian Res. 2006, 148, 145-180. [CrossRef]

45. Martin, A.P.; Condon, D.J.; Prave, A.R.; Lepland, A. A review of temporal constraints for the Palaeoproterozoic large, positive carbonate carbon isotope excursion (the Lomagundi-Jatuli Event). Earth-Sci. Rev. 2013, 127, 242-261. [CrossRef]

46. Bachan, A.; Kump, L.R. The rise of oxygen and siderite oxidation during the Lomagundi Event. Proc. Natl. Acad. Sci. USA 2015, 112, 6562-6567. [CrossRef]

47. Marques, J.C.; Jost, H.; Creaser, R.A.; Frantz, J.C.; Osório, R.G. Age of arsenopyrite gold-bearing massive lenses of the Mina III and its implication on exploration, Crixás greenstone belt, Goiás, Brazil. In Proceedings of the 3rd Brazilian Symposium on Metallogeny, Gramado, Brazil, 2-5 June 2013; p. 2.

48. De Tarso Ferro de Oliveira Fortes, P.; Cheilletz, A.; Giuliani, G.; Féraud, G. A Brasiliano age (500 \pm 5 Ma) for the Mina III gold deposit, Crixás greenstone belt, central Brazil. Int. Geol. Rev. 1997, 39, 449-460. [CrossRef]

49. Danni, J.; Ribeiro, C. Caracterização estratigráfíca da seqüência vulcano-sedimentar de Pilar de Goiás e de Guarinos, Goiás. In Proceedings of the XXX Congresso Brasileiro de Geologia, Recife, Brazil, 29 October-4 November 1978; pp. 582-596. 
50. Jost, H.; Scandolara, J.E. Características estruturais, petrográficas e geoquímicas de enxame de diques máficos intrusivo em rochas metassedimentares do greenstone belt de Crixás, Goiás. Geol. USP Série Científica 2010, 10, 118-134. [CrossRef]

51. De Tarso Ferro de Oliveira Fortes, P.; Giuliani, G.; Takaki, T.; Pimentel, M.; Teixeira, W. Aspectos geoquímicos do depósito aurífero Mina III, greenstone belt de Crixás, Goiás. Geochim. Bras. 1995, 9. [CrossRef]

52. Fougerouse, D.; Micklethwaite, S.; Ulrich, S.; Miller, J.; Godel, B.; Adams, D.T.; McCuaig, T.C. Evidence for two stages of mineralization in West Africa's largest gold deposit: Obuasi, Ghana. Econ. Geol. 2017, 112, 3-22. [CrossRef]

53. Fougerouse, D.; Micklethwaite, S.; Tomkins, A.G.; Mei, Y.; Kilburn, M.; Guagliardo, P.; Fisher, L.A.; Halfpenny, A.; Gee, M.; Paterson, D. Gold remobilisation and formation of high grade ore shoots driven by dissolution-reprecipitation replacement and Ni substitution into auriferous arsenopyrite. Geochimica et Cosmochimica Acta 2016, 178, 143-159. [CrossRef]

54. Gloyn-Jones, J.; Kisters, A. Regional folding, low-angle thrusting and permeability networks: Structural controls of gold mineralization in the Hope reef at Fairview Mine, Barberton Greenstone Belt, South Africa. Ore Geol. Rev. 2018, 102, 585-603. [CrossRef]

55. Ramsay, J.G.; Huber, M.I. The Techniques of Modern Structural Geology, Folds and Fractures; Academic Press: London, UK, 1987; Volume 2, pp. 309-700.

56. Bell, T.; Ham, A.; Hickey, K. Early formed regional antiforms and synforms that fold younger matrix schistosities: Their effect on sites of mineral growth. Tectonophysics 2003, 367, 253-278. [CrossRef]

57. Micklethwaite, S.; Cox, S.F. Progressive fault triggering and fluid flow in aftershock domains: Examples from mineralized Archaean fault systems. Earth Planet. Sci. Lett. 2006, 250, 318-330. [CrossRef]

58. Sibson, R.H. Arterial faults and their role in mineralizing systems. Geosci. Front. 2019, 10, 2093-2100. [CrossRef]

59. Santosh, M.; Maruyama, S.; Komiya, T.; Yamamoto, S. Orogens in the evolving Earth: From surface continents to 'lost continents' at the core-mantle boundary. Geol. Soc. Lond. Spec. Publ. 2010, 338, 77-116. [CrossRef]

60. Miller, J.; Blewett, R.; Tunjic, J.; Connors, K. The role of early formed structures on the development of the world class St Ives Goldfield, Yilgarn, WA. Precambrian Res. 2010, 183, 292-315. [CrossRef]

61. Goodwin, A.; Smith, I. Chemical discontinuities in Archean metavolcanic terrains and the development of Archean crust. Precambrian Res. 1980, 10, 301-311. [CrossRef]

62. Johnson, T.E.; Brown, M.; Goodenough, K.M.; Clark, C.; Kinny, P.D.; White, R.W. Subduction or sagduction? Ambiguity in constraining the origin of ultramafic-mafic bodies in the Archean crust of NW Scotland. Precambrian Res. 2016, $283,89-105$. [CrossRef]

63. Vanderhaeghe, O.; Guergouz, C.; Fabre, C.; Duchêne, S.; Baratoux, D. Secular cooling and crystallization of partially molten Archaean continental crust over $1 \mathrm{Ga}$. Comptes Rendus Geosci. 2019, 351, 562-573. [CrossRef]

64. Vidal, M.; Gumiaux, C.; Cagnard, F.; Pouclet, A.; Ouattara, G.; Pichon, M. Evolution of a Paleoproterozoic "weak type" orogeny in the West African Craton (Ivory Coast). Tectonophysics 2009, 477, 145-159. [CrossRef]

65. Lompo, M. Paleoproterozoic structural evolution of the Man-Leo Shield (West Africa). Key structures for vertical to transcurrent tectonics. J. Afr. Earth Sci. 2010, 58, 19-36. [CrossRef]

66. Štıpská, P.; Schulmann, K.; Thompson, A.; Ježek, J.; Kröner, A. Thermo-mechanical role of a Cambro-Ordovician paleorift during the Variscan collision: The NE margin of the Bohemian Massif. Tectonophysics 2001, 332, 239-253. [CrossRef] 